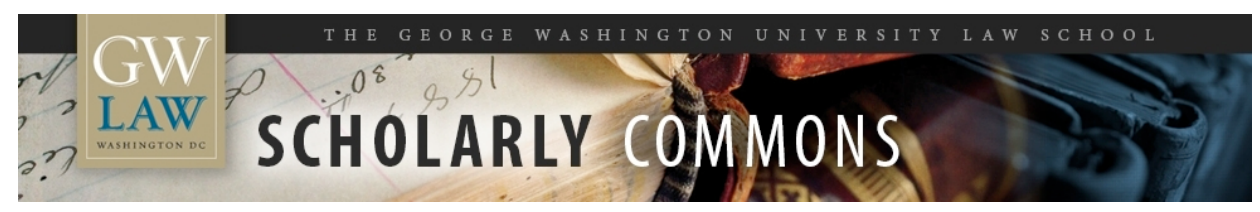

GW Law Faculty Publications \& Other Works

Faculty Scholarship

2013

\title{
Mapping the Law of WTO Accession
}

Steve Charnovitz

George Washington University Law School, scharnovitz@law.gwu.edu

Follow this and additional works at: https://scholarship.law.gwu.edu/faculty_publications

Part of the Law Commons

\section{Recommended Citation}

Steve Charnovitz, Mapping the Law of WTO Accession in WTO AT TEN: GOVERNANCE, DISPUTE SETTLEMENT AND DEVELOPING COUNTRIES (Merit E. Janow, Victoria Donaldson \&Alan Yanovich, eds., Juris Publishing, Inc., Forthcoming)

This Article is brought to you for free and open access by the Faculty Scholarship at Scholarly Commons. It has been accepted for inclusion in GW Law Faculty Publications \& Other Works by an authorized administrator of Scholarly Commons. For more information, please contact spagel@law.gwu.edu. 


\title{
Mapping the Law of WTO Accession
}

\author{
Steve Charnovitz*
}

This article explores the looming and controversial legal issues surrounding the law of WTO accession. Many of the recent accession negotiations have been quite detailed with WTO members nailing down numerous commitments by the applicant government (e.g., Saudi Arabia) seeking to join the WTO. ${ }^{1}$ If these commitments are not implemented, the governments that were the most vociferous in seeking them may invoke WTO dispute settlement. In September 2006, the first cases commenced at the WTO alleging a violation of an accession commitment. In those proceedings, there will be pleadings on and consideration by the panel as to (whether and) why an accession commitment is enforceable in WTO law. The answer may seem obvious, but when one delves into the question, the answer is hardly clear. Few commentators have addressed this point and those that have, in my opinion, have not produced a satisfactory answer. Developing a coherent legal explanation as to why a commitment in an accession protocol is enforceable is a necessary first step for thinking through other

\footnotetext{
${ }^{1 *(C) S t e v e ~ C h a r n o v i t z . ~ T h i s ~ a r t i c l e ~ c o v e r s ~ e v e n t s ~ t h r o u g h ~} 7$ November 2006. Thanks to Sungjoon Cho, Lothar Ehring, David Gantz, Mitsuo Matsushita, Petros Mavroidis, Jide Nzelibe, Julia Ya Qin, and to my GWU faculty colleagues Don Clarke, David Fontana, Susan Karamanian, Sean Murphy, and Ed Swaine for their helpful suggestions. This article will appear in a forthcoming volume to be published by Juris Publishing that will include the papers presented at the "WTO at Ten" Conference held at Columbia University in 2006. (The editors for the volume are Merit E. Janow, Victoria Donaldson, and Alan Yanovich.) This article is posted on SSRN with the approval of Juris Publishing.

As used in this article, an "applicant" government is the state or separate customs territory that is seeking to join the WTO pursuant to Article XII (Accession) of the Marrakesh Agreement Establishing the WTO ("WTO Agreement”). An "acceded" or "acceding” member is an applicant that has succeeded in joining the WTO. An "original member" is a government that joined the WTO under Article XI (Original Membership) of the WTO Agreement. An "incumbent member" is a member that joined under either Article XI or XII and is a member at the time that a new accession protocol is approved. Unlike the EC - Bananas III panel, I will not use the term "new" to designate WTO members that joined the WTO via accession. See Panel Report, European Communities - Regime for the Importation, Sale and Distribution of Bananas, Complaint by Guatemala and Honduras, WT/DS27/R/GTM, WT/DS27/R/HND, adopted 25 September 1997, as modified by Appellate Body Report, WT/DS27/AB/R, DSR 1997:II, 695, para. 7.91. I do not follow that panel's nomenclature because an acceding member, years later, is hardly a new member.
} 
questions such as the proper approach for interpreting accession commitments within the context of general WTO law. This article seeks to fill the gap.

Dispute settlement in the World Trade Organization (WTO) has proven to be a more legalized than many in the trade community anticipated during the Uruguay Round of trade negotiations that established the WTO. ${ }^{2}$ The WTO panel system has been described as “judicial” by the Appellate Body, which has supported this observation by making clear that first-level panels “necessarily” have to consider its views, and to “rely” on its reasoning and rulings, and that the Appellate Body’s decisions are meant to provide "interpretive guidance for future panels . . ..”3 During the past decade, the dispute system has successfully grappled with many controversial legal issues, and seems prepared to continue doing so alongside the languishing Doha round negotiations.

With regard to the enforceability of accession commitments, one can expect future panels to articulate a rationale for where accession commitments fit into WTO law and why they are enforceable. My article seeks to inform the pleadings that will be made by governments to the panels and the ultimate resolution of these difficult questions. In my view, predicating enforcement on the wrong reason will have negative repercussions for future cases and for the WTO political process.

The most basic challenge to analyzing accession is that there is no common vocabulary for distinguishing the several kinds of provisions in accession protocols. This article proposes a new accession vocabulary and devises a new typology of accession commitments by dividing the universe

\footnotetext{
${ }^{2}$ Richard H. Steinberg, Judicial Lawmaking at the WTO: Discursive, Constitutional, and Political Constraints, 98 AM. J. INT'L L. 247, 248 (2004); Peter van den Bossche, The Making of the "World Trade Court": The Origins and Development of the Appellate Body of the World Trade Organization, in Key Issues in WTO Dispute Settlement. The First Ten YeARs 63, 79 (Rufus Yerxa \& Bruce Wilson eds., 2005).

${ }^{3}$ Appellate Body Report, India - Quantitative Restrictions on Imports of Agricultural, Textile and Industrial Products, WT/DS90/AB/R, adopted 22 September 1999, DSR 1999:IV, 1763, para. 149 (noting the "judicial function” of panels); Appellate Body Report, United States - Import Prohibition of Certain Shrimp and Shrimp Products - Recourse to Article 21.5 of the DSU by Malaysia, WT/DS58/AB/RW, adopted 21 November 2001, DSR 2001:XIII, 6481, para. 107 (discussing the precedential weight of Appellate Body decisions).
} 
of commitments into conceptual categories that turn on whether the protocol adds or diminishes the obligation of the acceding party, the incumbent parties, or the WTO itself. In addition to being beneficial for lawyers seeking enforcement, this typology can also be useful to economists, political scientists, and others who analyze different trends in WTO accession negotiations, including the important ongoing talks with Russia and Vietnam.

The article proceeds as follows: Part I provides background on the WTO rules regarding accession and the process of acceding. Part II analyzes the WTO-plus and WTO-minus concepts in accession negotiations and presents some conceptual refinements. Part III puts forward a legal explanation of why WTO accession protocols are enforceable. Part IV discusses some challenges of interpretation and suspending concessions or other obligations in WTO accession implementation disputes. Part V draws conclusions.

\section{Background on the WTO Rules for Accession and the Accession Process}

Most WTO members are states, and the remaining few are separate customs territories (e.g., Hong Kong, China). Membership is obtained either by being original members or through accession. ${ }^{4}$ As time goes on, the percent of WTO members who join through accession will increase. Today, the WTO has 149 members, 21 of which (14 percent) entered via accession since the WTO treaty went into force in 1995. The WTO also has 30 candidate countries now being vetted. If universal membership ${ }^{5}$ is ever achieved, the percent of the WTO membership entering via accession would be 35 percent (or more).

\footnotetext{
${ }^{4}$ See Marrakesh Agreement Establishing the World Trade Organization ("WTO Agreement), arts. XI, XII.

${ }^{5}$ The WTO leadership often says that the WTO aspires to universal membership. See, e.g., Renato Ruggiero, “The Multilateral Trading System at Fifty, 16 January 1998, (“A third priority is to continue the momentum towards universal membership of the system. And this means completing the 32 accession negotiations currently underway without compromising the system's basic rules, rights and obligations.”).
} 
A government seeking to join the WTO market faces significant barriers to entry.

Governments have to assiduously negotiate their way in. ${ }^{6}$ This political hurdle is much greater now than it was in the pre-WTO era. Back 1965, Gerald Curzon, the leading commentator of that era on the General Agreement on Tariffs and Trade (GATT), wrote that on the whole, the GATT's accession "arrangement is biased in favour of newcomers. Established members of GATT do not normally try to drive too hard a bargain in payment of concessions which they made to third countries many years before."7 Nowadays established members of the WTO often do drive a hard bargain. For example, the Russian Federation has been trying to join since June 1993, and the process is far from over. ${ }^{8}$ As countries get close to the finish line, the final momentum will often come from favorable geo-political winds.

Unlike most other multilateral organizations, where the membership process for states is routine, transparent, and predictable, ${ }^{9}$ the WTO imposes significant barriers to entry because incumbent members use the lure of membership to induce economic policy changes in the applying country. Such linkage appears to be driven by both normative and procedural reasons. The normative reason is that the conventional wisdom in and around the WTO is that locking in economic changes in

\footnotetext{
${ }^{6}$ Mitsuo Matsushita, Thomas J. Schoenbaum \& Petros C. Mavroidis, The World Trade ORGANIZATION 11 ( $2^{\text {nd }}$ ed. 2006) ("Accession to the WTO is a difficult and time-consuming process.”).

${ }^{7}$ Gerald Curzon, Multilateral Commercial Diplomacy 36 (1965).
}

${ }^{8}$ Bush Hangs Tough as Impasse Blocks Moscow's Efforts to Join WTO, AUSTRALIAN, 17 July 2006, at 12 (noting the sticking point of the Russian concern about the safety of U.S. beef and pork). In July 2006, the G8 adopted a Summit Statement on Trade that, among other points, underlined "support [for] Russia’s expeditious accession to the WTO in accordance with the rules that apply to all of its members.” See <http://en.g8russia.ru/docs/16.html>.

${ }^{9}$ The Organisation for Economic Co-operation and Development (OECD) also has an accession process. See James Salzman \& Julio Bacio Terracino, Labor Rights, Globalization and Institutions: The role and Influence of the Organisation for Economic Cooperation and Development, in SoCIAL IsSUES, GLOBALISATION AND INTERNATIONAL INSTITUTIONS 311, 350-54 (Virginia A. Leary \& Daniel Warner eds., 2006) (discussing consideration of labor rights in connection with Korean's accession to the OECD). 
an applicant country will redound to the benefit of that country and will also help exporters and investors of incumbent members. The procedural reason is that a consensus of incumbent members is required in order to admit an applicant government. ${ }^{10}$

The use of consensus decisionmaking is not apparent in the text of Article XII (Accession) of the Marrakesh Agreement Establishing the World Trade Organization (“WTO Agreement”) that states:

1. Any State or separate customs territory possessing full autonomy in the conduct of its external commercial relations and of the other matters provided for in this Agreement and the Multilateral Trade Agreements may accede to this Agreement, on terms to be agreed between it and the WTO. Such accession shall apply to this Agreement and the Multilateral Trade Agreements annexed thereto.

2. Decisions on accession shall be taken by the Ministerial Conference. The Ministerial Conference shall approve the agreement on the terms of accession by a two-thirds majority of the Members of the WTO. ${ }^{11}$

3. Accession to a Plurilateral Trade Agreement shall be governed by the provisions of that Agreement.

Consensus is requisite because before an accession protocol can reach the Ministerial Conference (or General Council acting for it ${ }^{12}$ ), it needs to be approved by consensus in the Working Party that negotiates with the applicant government and draws up the formal negotiating terms. (Moreover, the Working Party itself has to be established by consensus.) In addition (with one exception), the practice has been for the Ministerial Conference or General Council to approve accession protocols by

\footnotetext{
${ }^{10}$ An incumbent member might join the consensus yet nonetheless decide to withhold its own application of the WTO Agreement to the new member. This practice is provided for in Article XIII (Non-Application) of the WTO Agreement. The United States has done this on several occasions.

${ }^{11}$ Presumably this means two-thirds of the entire WTO membership. Compare WTO Agreement, art. IX:1 which provides for a simple majority "of the votes cast."

${ }^{12}$ The WTO practice is that the General Council has inter-sessional authority under WTO Agreement, Article IV:2 to approve accession agreements. One could question whether this is ultra vires because in its provisions on WTO decisionmaking, the WTO Agreement states that both "The Ministerial Conference and the General Council shall have the exclusive authority to adopt interpretations .....” Id. art. IX:2. If it is always the case that the General Council may stand in for the Ministerial Conference, then what is the meaning of the words that specifically mention the General Council in Article IX:2? Alternatively, if Article IX:2 gives independent grants of authority to both Ministerial Conference and General Council, then how can that function be exclusive?
} 
consensus. ${ }^{13}$ Indeed, consensus is the regular approach to all legislative/political decisionmaking the WTO. $^{14}$

The text of Article XII does not reveal how decentralized the process of accession actually is. Instead of one negotiation between the WTO and the applicant, there are multiple, simultaneous negotiations between the applicant and each incumbent member hoping to demand “terms.” Only after each incumbent member is satisfied do all of these individual negotiating results get folded together into the overall accession package. ${ }^{15}$

Article XII of the WTO Agreement is based on the text of Article XXXIII (Accession) of the GATT which states that a government may accede to the GATT on terms to be agreed between such government and the GATT contracting parties, acting jointly, based on a two-thirds vote. Back in 1947, the GATT was intended to be absorbed into the planned International Trade Organization (ITO) and its membership rule was based on majority voting without any mention of negotiated terms. ${ }^{16}$

\footnotetext{
${ }^{13}$ Mary E. Footer, An Institutional AND Normative AnAlysis of THE WorLd Trade ORGANIZATION 248 (2006) (contrasting the consensus practice with the exceptional case of Ecuador whose accession was approved through a postal ballot).

${ }^{14}$ Debra P. Steger, Challenges to the Legitimacy of the WTO, in LAW IN THE SERVICE OF HUMAN Dignity. EsSAYS In HonOuR OF FlORENTINO FELICIANO 202, 215-16 (Steve Charnovitz, Debra P. Steger \& Peter van den Bossche eds., 2005).

${ }^{15}$ See WTO, "How to Become a Member of the WTO," available at $<$ http://www.wto.org/english/thewto_e/acc_e/acces_e.htm>, explaining that "Because each accession Working Party takes decisions by consensus, all interested WTO Members must be in agreement that their individual concerns have been met and that outstanding issues have been resolved in the course of their bilateral and multilateral negotiations.” See, e.g., “Georgia Retaliatory Move Block’s Russia’s Bid to Join WTO,” Seattle Post-Intelligencer, 13 October 2006, at A3. That said, not everything that an incumbent member demands is necessarily intended to be memorialized in the accession protocol. In other words, there can be (non-monetary) side payments on issues unrelated to the WTO. If the terms that one incumbent extracts from the applicant prove unacceptable to other incumbent members, then those terms may well be omitted from the protocol due to the consensus rule.

${ }^{16}$ See Charter of the International Trade Organization (not in force), arts. 71.2, 75.2, available at $<$ http://www.wto.org/english/docs_e/legal_e/prewto_legal_e.htm>.
} 
Article XII does not state any principles for accession negotiations and does not include any parameters for what “terms” may be “agreed” between the WTO and the applicant country. ${ }^{17}$ In late 1994, just before the WTO came into existence, there was a principle put forward in the GATT Council that "accession negotiations should be limited to issues related to GATT rights and obligations including market access to the applicant country or territory.”18 That did not transpire in WTO practice however.

In view of the asymmetric bargaining position of the applicant versus the incumbent members, the terms agreed will typically include only commitments made by the applicant. ${ }^{19}$ Nevertheless because the Preamble to the WTO Agreement heralds "reciprocal and mutually advantageous arrangements” among parties, one can also imagine that accession negotiations could lead to liberalization commitments being extracted from incumbent WTO members. In WTO practice, however, incumbents have not been inspired to make their own offers to liberalize trade of interest to the applicant.

When the WTO agrees to admit an applicant country, it does so through the adoption of an Article XII decision that approves the accession protocol. The WTO Secretariat has identified the terms that are common to all accession protocols, ${ }^{20}$ so that text can be considered the "Standard Protocol,” and is presented below in excerpted form:

\footnotetext{
${ }^{17}$ Julia Ya Qin, “WTO-Plus” Obligations and their Implications for the World Trade Organization Legal System, 37 J. WORLD TRADE 483, 487 (2003). My article builds upon Qin's pioneering study.

${ }^{18}$ WTO, Guide to GATT LAW AND PRACTICE 1020 (1995). This principle was stated by the Chairman of the Council and said to arise out of consultations with delegations. It was listed as one of 10 "points" of "an indicative nature." Id.

${ }^{19}$ Constantine Michalopoulos, WTO Accession, in Development, TrAde, AND the WTO 61, 62 (Bernard Hoekman, Aaditya Mattoo \& Philip English eds., 2002) (“Incumbent members can ask the applicant to reduce the level of protection in its markets, but the reverse does not usually occur”).

${ }^{20}$ The Standard Protocol appears on page 42 of “Technical Note on the Accession Process," Note by the Secretariat, WT/ACC/10/Rev.3 (28 November 2005) [hereinafter “Secretariat Note”].
} 


\title{
PROTOCOL ON THE ACCESSION OF THE REPUBLIC OF [name of Applicant]
}

\author{
Preamble
}

The World Trade Organization (hereinafter referred to as the "WTO"), pursuant to the approval of the General Council of the WTO accorded under Article XII of the Marrakesh Agreement Establishing the World Trade Organization (hereinafter referred to as "WTO Agreement"), and the Republic of ...[name of applicant]... (hereinafter referred to as "[short form of name]"),

Taking note of the Report of the Working Party on the Accession of ...[name of applicant]... to the WTO in document WT/ACC/[...] (hereinafter referred to as the "Working Party Report"),

Agree as follows:

\section{PART I - GENERAL}

1. Upon entry into force of this Protocol, ... [name of applicant]... accedes to the WTO Agreement pursuant to Article XII of that Agreement and thereby becomes a Member of the WTO.

2. The WTO Agreement to which ...[name of applicant]... accedes shall be the WTO Agreement as rectified, amended or otherwise modified by such legal instruments as may have entered into force before the date of entry into force of this Protocol. This Protocol, which shall comprise the commitments referred to in paragraph ... [list of relevant commitment paragraph numbers]... of the Working Party Report, shall be an integral part of the WTO Agreement.

3. Except as otherwise provided for in the paragraphs referred to in paragraph ...[list of relevant paragraphs numbers]... of the Working Party Report, those obligations in the Multilateral Trade Agreements annexed to the WTO Agreement that are to be implemented over a period of time starting with the entry into force of that Agreement shall be implemented by ....[name of applicant]... as if it had accepted that Agreement on the date of its entry into force.

\section{PART II - SCHEDULES}

4. The Schedules annexed to this Protocol shall become the Schedule of Concessions and Commitments annexed to the General Agreement on Tariffs and Trade 1994 (hereinafter referred to as the "GATT 1994") and the Schedule of Specific Commitments annexed to the General Agreement on Trade in Services (hereinafter referred to as "GATS") relating to ...[name of applicant]... $\cdots$

\section{PART III - FINAL PROVISIONS}

6. This Protocol shall be open for acceptance, by signature or otherwise, by ...[name of applicant]... until ...[date]...

7. This Protocol shall enter into force on the thirtieth day following the day of its acceptance.

$\cdots$

9. This Protocol shall be registered in accordance with the provisions of Article 102 of the Charter of the United Nations. 
Typically, WTO Accession Protocols resemble this Standard Protocol, sometimes with minor variation. Yet Protocol for China stands apart. It is a detailed agreement running just over 100 pages that teems with specific commitments. ${ }^{21}$ Whether the China approach will be used in future complex accessions (e.g., Vietnam and Russia) remains to be seen. Note that although there has been a Standard Protocol, the terms of each particular accession not standard. Each negotiation is separate and has led to a discrete package of terms incorporated into the Working Party report.

After the WTO Ministerial Conference (or General Council) approves the accession protocol, the acceding government must complete its "acceptance” process within the time limits prescribed in the accession protocol (see para. 6 above). The amount of time that a Protocol gives for national acceptance varies considerably. The lowest was 22 days for Oman and the highest was just under nine months for Panama. ${ }^{22}$ Three countries were given less than three months, but the typical grant of time is three to six months. In all instances so far, the acceding country has acted in time. The data suggest that in practice, the time limits are individualized with appreciation for domestic parliamentary hurdles in the applicant country.

No known limit exists on the competence of the WTO to include a particular term within an accession agreement. Although WTO dispute settlement is a judicial system, the Dispute Settlement Body (DSB) is not usually perceived as having jurisdiction to consider the appropriateness of demands being made in an accession negotiation. Moreover, the party with the greatest interest, the applicant

\footnotetext{
${ }^{21}$ Protocol on the Accession of the People’s Republic of China, WT/L/432 (23 November 2001) [hereinafter China Protocol]. As John Jackson has noted, the China Protocol "in some ways departs from the normal rules of the WTO by applying a somewhat more stringent set of rules to the China case.” JoHn H. JACKSON, SOVEREIGNTY, THE WTO, AND CHANGING FUNDAMENTALS OF INTERNATIONAL LAW 110 (2006).

${ }^{22}$ Oman acted on the first day.
} 
country, does not have standing to invoke WTO dispute settlement. ${ }^{23}$ When unique obligations are agreed to in an accession negotiation, and then are invoked in dispute settlement, a panel may be faced with having to consider whether it can adjudge the propriety of such a provision under Article XII, in the course of interpreting the provision and deciding how to enforce it. Such a panel could, without embarrassment, hold that it lacks authority to question whether an accession agreement agreed to by both the WTO and the applicant country can be ultra vires under WTO law.

Although each acceding WTO member is obliged to follow all the rules in the WTO Agreement, such member is also presumably obliged to follow the rules embedded in its own Accession Protocol. I say "presumably” because I am unaware of any holding in international trade law jurisprudence on precisely that point. Yet surely that is the expectation of all WTO stakeholders and such enforceability would be consistent with the large amount of time and negotiating energy devoted to hammering out the details of accession accords.

Many commentators have argued that WTO accession disciplines are enforceable. For example:

All the obligations in this [accession] package are enforceable through the Dispute Settlement Understanding of the WTO. ${ }^{24}$ WTO Secretariat

As such, the [Accession] Protocol becomes part of a "covered agreement" for the purpose of the Dispute Settlement Understanding, and its provisions are fully enforceable through the WTO dispute settlement procedure. ${ }^{25}$ Julia Ya Qin

The commitments listed in the Protocol of Accession would be legally binding and enforceable via the WTO Dispute Settlement Understanding. ${ }^{26}$ Anna Lanoszka

\footnotetext{
${ }^{23}$ Appellate Body Report, United States - Import Prohibition of Certain Shrimp and Shrimp Products, WT/DS58/AB/R, adopted 6 November 1998, DSR 1998:VII, 2755, para. 101 ("It may be well to stress at the outset that access to the dispute settlement process of the WTO is limited to Members of the WTO.”).

${ }^{24}$ Secretariat Note, supra note 20, at 2.

${ }^{25}$ Qin, supra note 17 , at 509.

${ }^{26}$ Anna Lanoszka, The World Trade Organization Accession Process, 35 J. WorLd TRADE 575, 583 (2001).
} 
[T] he combined Working Party Report and Protocol ... are binding international law cognizable by the WTO's dispute resolution bodies. ${ }^{27}$ Thomas $P$. Holt

Yet there is very little explanation by commentators as to why accession agreements are enforceable.

To be sure, the rationale for enforceability is clear for some aspects of an accession discipline. The market access provisions for goods and services are enforceable because they are annexed to the GATT or to the General Agreement on Trade in Services (GATS) as indicated in the fourth paragraph of standard protocol. ${ }^{28}$ What is not clear is why the other commitments made in accession negotiations are enforceable, particularly the tailored rules for the acceding members. ${ }^{29}$ Except for China, such tailored commitments are not spelled out in detail in the accession protocol, but rather are incorporated there by reference to the specific commitments made in the Working Party report (see paragraph 2 in the Standard Protocol above). Those are the commitments to be discussed in this article.

\section{A New Paradigm of WTO-Plus and Minus Commitments}

Although there has been some writing by scholars and practitioners on the accession process, no generally accepted paradigm exists for rule-like provisions. The terms "WTO-plus" and "WTOminus” are often used by analysts to describe accession terms that do not match regular WTO rules. ${ }^{30}$

\footnotetext{
${ }^{27}$ Thomas P. Holt, CNOOC-UNOCAL and the WTO: Discriminatory Rules in the China Protocol are a Latent Threat to the Rule of Law in the Dispute Settlement Understanding, 15 PAC. RIM L. \& POL'Y 457, 457 (2006).

${ }^{28}$ See General Agreement on Tariffs and Trade (GATT) art. II:7 and General Agreement on Trade in Services (GATS) art. XXIX.

${ }^{29}$ Note that the plurilateral Agreement on Government Procurement has its own provision for accession in Article XXIV:2 which states that WTO member governments "may accede to this Agreement on terms to be agreed between that government and the Parties." The terms agreed are inscribed in Appendixes which are defined in the Agreement as being an "integral part" of the Agreement itself. Id. art. XXIV:12. See, e.g., Accession of Iceland, GPA/43 (9 October 2000). Thus, the terms for Government Procurement accession do not contain anything symmetric to the rule-like disciplines in WTO accessions.

${ }^{30}$ See Qin, supra note 17; Rebecca Povarchuk, Cambodia's WTO Accession: A Strenuous but Necessary Step for a Poor Nation Seeking Economic Prosperity, 13 PAC. RIM. L. \& POL’y 634 (2004); Secretariat Note, supra note 20, at 37-38.
} 
For example, one commentary (by Jolita Butkeviciene, Michiko Hayashi, Victor Ognivtsev and Tokio Yamaoka) defines “WTO-plus” as commitments by the applicant in areas not addressed by rules in WTO agreements. ${ }^{31}$ That definition fits practice. Furthermore, they define "WTO-minus" to be the "non-application of the rights under WTO Agreements available to acceding WTO members such as transition periods, and tariffication and special safeguards for agricultural products. ${ }^{32}$ That usage is comprehensible, but seems inexact because it presumes that the transition periods made available to original WTO members in 1995 have become "rights" of applicant countries several years later. Yet as the third paragraph in the Standard Protocol makes clear, the WTO has tended to insist that the transition period clock start on the date of the entry into force of the WTO Agreement (i.e., January 1995), not the date of the entry into force of individual accessions. ${ }^{33}$ One might perceive that treatment as unfair to the applicant, but such unfairness is quite different from saying that the applicant government is being denied its legal "rights."

In thinking about whether that treatment is unfair, one should recall that the transition periods in the WTO Agreement ${ }^{34}$ presumably reflected the fact that in 1994 many of the new disciplines were novel. Over a decade later, there is no reason to reset the transition clock for each acceding country

\footnotetext{
${ }^{31}$ Jolita Butkeviciene, Michiko Hayashi, Victor Ognivtsev \& Tokio Yamaoka, Terms of WTO Accession, in UNCTAD, WTO ACCESSIONS AND DEVElopMENT PoliCIES, UNCTAD, DITC/TNCD/11 (2001), at 155, 156.

${ }^{32} I d$. at 156.

${ }^{33}$ See Secretariat Note, supra note 20, at 2 ("The transition periods granted to original WTO Members during the Uruguay Round are not automatic to governments acceding under Article XII.”). Thus, the more deferential accession practice of the GATT acquis was not brought forward into the WTO. During the GATT era, accession protocols typically had a provision substituting the date of each Protocol for the date of the GATT for the purpose of listed GATT obligations. See GUIDE TO GATT LAW AND PRACTICE, supra note 18, at 1021-22 \& n. 18.

${ }^{34}$ For example, Article 14 of the Agreement on the Application of Sanitary and Phytosanitary Measures (SPS Agreement) provided a two-year transition to developing countries for most disciplines. In my view, a country joining the WTO in 2006 should not need such a transition as the country does not have to join until it is ready to comply.
} 
because that country will have had time to adjust to WTO requirements, particularly given the fact that the applicant country will have spent several years as a WTO observer. ${ }^{35}$

\section{A Brief Discourse on WTO "Rights"}

The pervasive references to the "rights" of WTO members in the literature on accession necessitates a brief detour. As I have written elsewhere, ${ }^{36}$ the general concept of WTO "rights" is difficult to comprehend. ${ }^{37}$ If by WTO rights, one means the procedural right to invoke dispute settlement so as to allege a violation (or a non-violation that nullifies and impairs), then that usage is unobjectionable. If by WTO rights, one means that a WTO member has a right to expect other WTO members to adhere to their obligations under WTO law, then that usage is comprehensible, but would seem to be merely noting an intended beneficiary of the WTO law obligation. ${ }^{38}$ But if by WTO rights, one means that a WTO member has a substantive right to a defined trade benefit or result like an

\footnotetext{
${ }^{35}$ On the other hand, one could argue that the laggards in joining the WTO are precisely those countries that will have the greatest legal and structural impediments at home, and therefore are most in need of extra time for domestic implementation of WTO obligations.

${ }^{36}$ The Appellate Body’s GSP Decision, 3 WorLd Trade REV. 239, 241, 251-53 (2004). I am not denying that the traditional Hohfeldian construct may be useful in private law contexts.

${ }^{37}$ The usage is comprehensible when it refers to a right held by a particular member to the exclusion of others. See, e.g., Understanding on the Interpretation of Article XXVIII of GATT 1994, para. 1 (regarding a "redistribution of negotiating rights").

${ }^{38}$ For example, in a recent study of inter se agreements between WTO members in connection with Article 41 of the Vienna Convention on the Law of Treaties, one commentator suggests that if such an agreement has a provision allowing parties to derogate from WTO rules on subsidies, then that provision "would clearly affect the rights of all WTO Members, such as the right of not having the market distorted by subsidies that are considered particularly pernicious and have been outlawed." Fabrizio Pagani, Are Plurilateral Trade Agreements Possible Outside of the World Trade Organization?,40 J. WORLD TRADE 797, 805 (2006). My position is that the "right of not having the market distorted by subsidies” has no self-evident or independent content as a "right." Instead, its meaning can only be understood as the implication of a WTO rule.
} 
export, then that usage seems unjustified under WTO law because most rules are qualified by exceptions. $^{39}$

Admittedly, my view runs counter to the text of WTO Agreement and its annexes which refer to "rights and obligations" of members or to a "balance of rights and obligations." 40 Moreover, the Appellate Body has held that within the WTO single undertaking, “all WTO Members are bound by all the rights and obligations in the WTO Agreement and its Annexes 1, 2 and 3.”41

Nevertheless, I have yet to see any way of imbuing meaning to the term "rights" that is not circular or tautologous. ${ }^{42}$ Some WTO provisions purport to grant rights, but a close reading of them shows that they do not. ${ }^{43}$ For example, paragraph 1 of Article 2 (Basic Rights and Obligations) of the Agreement on the Application of Sanitary and Phytosanitary Measures (SPS Agreement) states that "Members have the right to take sanitary and phytosanitary measures necessary for the protection of human, animal or plant life or health, provided that such measures are not inconsistent with the

\footnotetext{
${ }^{39}$ For example, GATT art. XXI. If by WTO “right,” one means a retained opportunity to exercise national autonomy not given up when joining the WTO (i.e., a "reserved" right), then that usage is comprehensible, but then such rights stand outside WTO law and not available for a panel to balance against an obligation.

${ }^{40}$ For example, see WTO Agreement, art. X:3, 4; Understanding on Rules and Procedures Governing the Settlement of Disputes (DSU) arts. 1.1, 3.2, 3.3, 3.4, 19.2; GATS art. XIX:1; Agreement on TradeRelated Aspects of Intellectual Property Rights (TRIPS), art. 7; Marrakesh Protocol to GATT 1994, para. 3. See also GATT ad. art. XXVIII, para. 1(4) (referring to a “contractual right”).

${ }^{41}$ Appellate Body Report, Brazil - Measures Affecting Desiccated Coconut, WT/DS22/AB/R, adopted 20 March 1997, DSR 1997:I, 167, p. 13. See also Appellate Body Report, European Communities Regime for the Importation, Sale and Distribution of Bananas, WT/DS27/AB/R, adopted 25 September 1997, DSR 1997:II, 591, para. 154 (stating that a concession "may yield rights and grant benefits," but cannot diminish obligations).

${ }^{42}$ If the WTO "right” of A is merely the benefit that A derives from B's obligation to A under WTO rules, then how are the rights of $\mathrm{A}$ and the obligations of $\mathrm{B}$ to be balanced?

${ }^{43}$ But see Joost PauWelyn, Conflict of NoRms in Public InTERnATIOnAL LAW 398 (2003) (suggesting that the Agreement on Technical Barriers to Trade provides for explicit rights or permissions to restrict trade).
} 
provisions of this Agreement." Yet that does not seem like the kind of "right" that a proud people would chisel in stone.

In my view, the WTO Agreement should be read only as conveying obligations, not as granting rights. Thus with regard to a transition period for acceding WTO members, the specification of such a period is not itself a "right," but rather a temporal limitation on the extent of the obligation. In the one episode when an acceded member sought WTO assistance in vindicating an accession "right,” the WTO showed no interest in doing so. For example in 2002, Mongolia sought the WTO’s help in keeping a tariff on cashmere that was legal under Mongolia’s GATT bindings, yet was nevertheless opposed by the International Monetary Fund (IMF). Mongolia asserted its "legal rights protected by the WTO,” but yielded to the IMF after the WTO failed to offer aid to Mongolia at the IMF in defense of the principle of a WTO right. ${ }^{44}$

Furthermore, in my view, the use of the term "right" in reference to WTO members distracts attentions from the inchoate rights truly at issue in the trading system - that is, the rights of individual economic actors. Although a treaty cannot extend a substantive right to all governments which the governments would not otherwise have, a treaty can accord rights to individuals in member countries where an individual might not otherwise have them. ${ }^{45}$ In any event, whatever the intellectual merits of this brief digression into the nature of "rights" in WTO law, it is clear that an acceding WTO member does not yet have any "rights” in WTO law.

\section{Determining the Legal Baseline of the Obligations of WTO Membership}

The starting point for analyzing accession protocols should be determining the legal baseline of the obligations of WTO membership. By a baseline I mean the body of obligations that would

\footnotetext{
${ }^{44}$ Damedin Tsogtbaatar, Mongolia's WTO Accession: Expectations and Realities of WTO Membership, WTO Secretariat, Case Study 29.

${ }^{45}$ See Steve Charnovitz, The WTO and the Rights of the Individual, 36 INTERECONOMICS - REVIEW OF EUROPEAN ECONOMIC POLICY 98 (2001).
} 
otherwise automatically devolve upon any applicant when it joins the WTO. When an applicant to the WTO makes a commitment to fulfill the requirements of WTO membership, that result is neither WTO-plus nor WTO minus.

One reason why accession protocols remain underanalyzed because insufficient work has been done to define the appropriate baselines (or benchmarks) for high income, developing, and least developed countries. In my view, the correct comparative baseline is the rules that exist for countries in that development class that were original members of the WTO.

Defining such a baseline is a daunting challenge, however, because of the multiplicity of transition periods available to developing or least-developed members. Although the least developed countries are defined, the developing countries are not and thus there can be a disagreement about which country is still in the "developing" stage. (In some ways, all countries are.) A logical baseline is a counterfactual that every applicant country joined the WTO on the date that the WTO went into force, and thus it would enjoy only the transition period that still remains for others. In other words, one would not start a transition period clock for each new member based on its individual date of entry. ${ }^{46}$

If an applicant country is not given the transition period that it would have if it were an original WTO member in that development class, then I would agree with the team of Butkeviciene et al. that this departs from normal WTO principles. But I would disagree with them such a situation should be referred to as "WTO-minus." ${ }^{47}$ Rather, I would call it "WTO-plus" because the applicant country takes on greater obligations than incumbent members have and do. I would reserve the term "WTO-

\footnotetext{
${ }^{46}$ Note that the countries that came into the WTO as "original” members after January 1995 had their transition period clocks set back to January 1995. WTO Agreement, art. XIV:2.

${ }^{47}$ See text accompanying supra note 32.
} 
minus” for situations when an applicant (or an incumbent) government takes on fewer obligations than called for in the otherwise applicable WTO rule. ${ }^{48}$

In late 2002, the WTO General Council approved a decision on Accession of Least-Developed Countries which set out "guidelines” for future accession negotiations. ${ }^{49}$ The Guidelines state that “transition periods/transitional arrangements foreseen under specific WTO Agreements . . . shall be granted in accession negotiations taking into account individual development, financial and trade needs." ${ }^{50}$ Moreover, the guidelines state that "Special and Differential Treatment” for applicant countries shall be applicable "from the date of entry into force of their respective Protocols of Accession.” ${ }^{51}$ Nevertheless, in the two accessions of least developed countries that have occurred since late 2002, Nepal and Cambodia, both Protocols utilized the standard provision to the effect that “except as otherwise provided ... those obligations in the Multilateral Trade Agreements annexed to the WTO Agreement that are to be implemented over a period of time starting with the entry into force of that Agreement shall be implemented ... [by the applicant] as if it had accepted that Agreement on the date of its entry into force.” ${ }^{52}$ This confirms that notwithstanding the 2002 guidelines, the presumptive baseline for applicant countries continues to be only the transition period available to original WTO

\footnotetext{
${ }^{48}$ Here I mean the rules set out in the WTO Agreement and its annexes. Sometimes WTO members are granted special waivers that allow them to break a rule for a limited number of years. For instance in 2001, the European Communities (EC) was permitted to continue WTO-illegal practices regarding bananas through 2005. In effect, that was legalized WTO-minus for an incumbent which I will disregard that for the purpose of calculating the WTO legal baseline.

49،Accession of Least Developed Countries,” WT/L/508 (20 January 2003).

${ }^{50}$ Id. para. 1.II.

${ }^{51} I d$.

${ }^{52}$ See, e.g., Accession of the Kingdom of Nepal, WT/MIN(03)/19 (11 September 2003), Annex, para. 3. The "multilateral trade agreements" are defined Annexes I-III of the WTO Agreement. WTO Agreement art. II:1.
} 
members. ${ }^{53}$ If an applicant country gets a longer transition period, that becomes a WTO-minus obligation for it.

\section{A New Typology of Accession}

In my view, a typology is needed for distinguishing various provisions in accession protocols. WTO-plus and WTO-minus obligations should be understood as obligations that are either greater than or less than what is required by regular WTO law. A WTO-minus obligation has less discipline than does the relevant WTO rule. A WTO-plus obligation is the opposite of that; it has greater discipline. In contemporary practice, some WTO-plus disciplines go well beyond the boundaries of the WTO to link in new issues not addressed by WTO rules.

Surveying the GATT in 1965, Gerald Curzon commented that upon a successful accession negotiation to the GATT, "a protocol of accession is drawn up whereby the acceding government becomes a contracting party and accepts the same rights and obligations as other governments.” ${ }^{„ 54}$ That was true 40 years ago, but today, applicant governments do not necessarily step into the same rights and obligations as incumbent governments enjoy. ${ }^{55}$

A useful typology for accession has to reflect the distinctive situations of applicants versus incumbent members. Start with the applicant: As Chart 1 shows, a WTO-plus obligation for the applicant exceeds the obligations required in the WTO baseline, and a WTO-minus obligation diminishes the obligations in the baseline:

\footnotetext{
${ }^{53}$ The decision to start Nepal's transition clock in 1995 has been criticized. See, e.g., Ramesh Bikram Karky, Nepal's Accession to the World Trade Organization, 7 J. WORLD InTELleCtuAl ProperTY 891, 915 (2004).

${ }^{54}$ CURZON, supra note 7 , at 36 .

${ }^{55}$ Peter Gallagher, The First Ten Years of the WTO 1995-2005, at 20 (2005) (“Once an economy is a Member, however, it is on the same footing as all other Members vis-à-vis the WTO agreements, except for any special conditions negotiated as part of its acceptance into the WTO.”) (emphasis added).
} 
Chart 1. WTO-Plus and WTO-Minus for the Applicant

\begin{tabular}{|l|l|}
\hline \multicolumn{1}{|c|}{ Nature of Obligation } & Example \\
\hline WTO-Plus: Above Baseline & $\begin{array}{l}\text { Greater transparency requirements } \\
\text { than incumbent members have }\end{array}$ \\
\hline WTO-Minus: Below Baseline & $\begin{array}{l}\text { Longer transition periods than } \\
\text { available to original members }\end{array}$ \\
\hline
\end{tabular}

Today, applicants to the WTO routinely sign on to permanent WTO-plus provisions and temporary

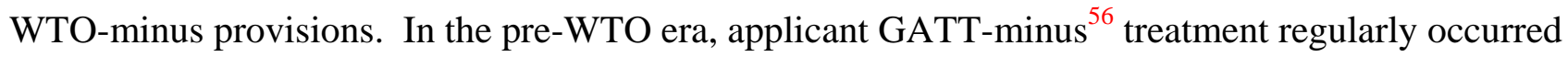
through the practice of joining the GATT through provisional accession that grandfathered in certain pre-existing violations, and then the later practice of inscribing specific reservations into accession protocols. ${ }^{57}$ In contrast, applicant GATT-plus commitments, in pre-WTO days, did not occur frequently.

In addition to detailing legal commitments by the acceded member, an accession agreement may also detail special rules regarding trade remedies by incumbent WTO members directed at the trade from the acceded member. A prime example of this are the unusual safeguards agreed to by China in the course of its WTO accession. ${ }^{58}$ Some analysts characterize them as "WTO-plus" while others tag them “WTO-minus.” For example, Will Martin (the World Bank’s expert on WTO

\footnotetext{
${ }^{56}$ This paper uses the terms “GATT-minus” and “GATT-plus” in an informal way because under the GATT practice of provisional application, there was not one baseline applicable to all parties.

${ }^{57}$ See KENNETH W. DAM, ThE GATT. LAW AND INTERNATIONAL ECONOMIC ORGANIZATION 347 (1970); GuIDE TO GATT LAW AND PRACTICE, supra note 18, at 1023.

${ }^{58}$ See, e.g., Yong-Shik Lee, The Special Safeguard Mechanism of China's Accession to the WTO. A Serious Step Backward from the Achievement of the Uruguay Round, 5 J. WORLD INTELLECTUAL PROPERTY 219 (2002).
} 
accession) calls the product-specific transitional safeguard a WTO-minus. ${ }^{59}$ Julia Qin has also called it a WTO-minus, the same term she has applied to the transitional textile safeguard mechanism. ${ }^{60}$ On the other hand, Dongli Huang calls the textile safeguard a WTO-plus, as does Nicholas Lardy. ${ }^{61}$ When the same provision is given opposite appellations by thoughtful analysts, then the need for more carefully defined categories becomes even more apparent.

In my view, both characterizations are inexact. Instead, I would typologize such safeguards as a reduced obligation of incumbent WTO members regarding its implementation of trade barriers against unwelcome trade from China. Accession agreements refer to this euphemistically as a “selective” provision, but I would call it what it is-discrimination authorized by the WTO. In other words, when some countries join the WTO, the WTO may insist that incumbent members be allowed to bar trade from the acceding economy in listed ways. I would characterize that deal as a reduced obligation on incumbent members and denote such unfavored-nation treatment as "incumbent WTOminus.”

Chart 2 below provides a Typology of Accession Disciplines for Applicants and Incumbents and illustrates three of the four cells:

\footnotetext{
${ }^{59}$ Will Martin, “WTO Accession: What's Involved?,” <http://siteresources.worldbank.org/INTRANETTRADE/Resources/WBI-Training/2884641152217173757/Session5_WillMartin.pdf>, at 18.

${ }^{60}$ Qin, supra note 17 , at 409 \& n. 31.

${ }^{61}$ Dongli Huang, Legal Interpretation of Paragraph 242 of the Report of the Working Party on the Accession of China Under the World Trade Organization Legal Framework, 40 J. WORLD TRADE 137 (2006) (stating that it is "sterner than normal”); Nicholas Lardy, China and the World Trade Organization, Fin. Times, 15 May 2002, at 2.
} 
Chart 2. Typology of WTO Accession Disciplines for Applicants and Incumbents

\begin{tabular}{|l|l|l|}
\hline & \multicolumn{1}{|c|}{ WTO-Minus } & \multicolumn{1}{|c|}{ WTO-Plus } \\
\hline Incumbent & Discriminatory safeguard & Occurs rarely \\
\hline Applicant & $\begin{array}{l}\text { Phase out of WTO-illegal } \\
\text { measures }\end{array}$ & $\begin{array}{l}\text { Non-trade commitments in } \\
\text { China's Protocol }\end{array}$ \\
\hline
\end{tabular}

Note that the categories above all manifest obligations, not so-called rights.

So far, few incumbent WTO-plus obligations have appeared in accession agreements. Craig

VanGrasstek has written:

The process of acceding to the WTO is a deliberately one-sided affair, with all of the requests and demands coming from the existing members and the full burden of adjustment falling on the acceding country. The applicant is not entitled to request additional benefits or concessions in excess of those stipulated in the WTO Agreements ....62

VanGrasstek is mostly right. Nevertheless, Incumbent WTO-plus lawmaking has occurred at least once. In Taiwan's ${ }^{63}$ Protocol, there is a provision which states:

\footnotetext{
${ }^{62}$ Craig VanGrasstek, Why Demands on Acceding Countries Increase Over Time: A ThreeDimensional Analysis of Multilateral Trade Diplomacy, in WTO ACCESSIONS AND DEVELOPMENT PoliciEs, supra note 31, at 78, 79. See also Marc Bacchetta \& Zdenek Drabek, "Effects of WTO Accession on Policy-Making in Sovereign States,” WTO Staff Working Paper DERD-2002,-02, April 2002, at 6-7 ("As any member of a 'club' has to abide by the rules of the club he/she wants to join, countries acceding into the WTO must accept the terms and conditions of the WTO as they stand.”).

${ }^{63}$ Taiwan acceded to the WTO under the name "Separate Customs Territory of Taiwan, Penghu, Kinmen and Matsu” and calls itself that at the WTO. In this article, I will use the shorter and universally recognized name, “Taiwan.” At China’s insistence, the WTO refers to Taiwan as "Chinese Taipei.”
} 
Exchange contracts which involve the currency of any Member or Chinese Taipei and which are contrary to the exchange control regulations of that Member or Chinese Taipei maintained or imposed consistently with the Articles of Agreement of the Fund or with the provisions of a special exchange agreement entered into pursuant to paragraph 6 of Article XV of the General Agreement 1994 or this Special Exchange Agreement, shall be unenforceable in the territories of Chinese Taipei or in the territories of any Member. ${ }^{64}$

This provision is technically WTO-plus because it imposes a new obligation on incumbents not to enforce such contracts in their own territory. ${ }^{65}$

During the pre-WTO era, there was at least one significant GATT-plus commitment by incumbents. For Hungary's accession, the European Communities (EC) stated that it expected to increase imports of consumer goods from Hungary, ${ }^{66}$ and in response, Hungary "took note” of this commitment. $^{67}$

In the course of WTO accessions, several applicants have made commitments to join (or seek to join) the Agreement on Government Procurement or the Agreement on Trade in Civil Aircraft (or both of these plurilateral agreements). For example, Georgia committed to signing on to the

\footnotetext{
${ }^{64}$ Accession of the Separate Customs Territory of Taiwan, Penghu, Kinmen and Matsu, WT/L/433 (23 November 2001), Annex II, Special Exchange Agreement, art II(3) (emphasis added) [hereinafter "Taiwan Special Exchange Agreement"]. The rationale for having the Special Exchange Agreement is that Taiwan is not a member of the IMF. See GATT arts. XV:6 (providing for special exchange agreements with non-IMF members and stating that such agreement with a GATT party "shall thereupon become part of its obligations" under the GATT), XV:9(a). In the GATT regime, the GATT negotiated special exchange agreements with Haiti, Indonesia, Sri Lanka, and Germany. GUIDE TO GATT LAW AND PRACTICE, supra note 33, at 437. The WTO needed to obtain Agreement with Taiwan because the IMF does not permit Taiwan to join.

${ }^{65}$ Compare GATT art. XVI (Exchange Arrangements). The origin of this accession provision goes back to the model Special Exchange Agreement drafted by the GATT Committee on Special Exchange Agreements in 1949. GATT, BISD II/11, Annex, art. VII:3.

${ }^{66}$ Protocol for the Accession of Hungary to the General Agreement on Tariffs and Trade, GATT, BISD 20S/3, para. 6; Gardner Patterson, The GATT: Categories, Problems and Procedures of Membership, 1992 Colum. Bus. L. REV. 7, 14 (reporting that this commitment made by the EC was "laboriously negotiated").

${ }^{67}$ Hungary Accession Protocol, supra note 66, para. 6.
} 
plurilateral agreement on Trade in Civil Aircraft ${ }^{68}$ and Estonia set a target date for completing its negotiations to join the Agreement on Government Procurement. ${ }^{69}$ Because joining plurilateral agreements is optional, some analysts call such commitments WTO-plus. Perhaps they are, but I am not calling them so here because joining the plurilateral agreement is an appropriate activity at any time. $^{70}$

Although the 2x2 cell typology in Chart 2 covers all of the rule-like provisions in accession agreements that apply to WTO members and applicants, accession agreements can also contain another species of commitment—obligations of the WTO itself. Because accession agreements are agreements between the WTO and the applicant country, it is possible for the WTO to take on greater or fewer obligations than the WTO otherwise has to its existing members.

These are provisions that increase obligations on the WTO’s decisionmaking and administrative bodies. An example of a greater obligation is the Taiwan Special Exchange Agreement in which the WTO agreed that whenever it consults with the IMF

... on exchange matters or in other appropriate cases particularly affecting Chinese Taipei, the WTO shall take measures, as are satisfactory to the Fund, to ensure effective presentation of Chinese Taipei's case to the Fund, including, without limitation, the transmission to the Fund of any views communicated by Chinese Taipei to the WTO. ${ }^{71}$

\footnotetext{
${ }^{68}$ Report of the Working Party on the Accession of Georgia to the World Trade Organization, WT/ACC/GEO/31 (31 August 1999), para. 125. Georgia did so.

${ }^{69}$ Report of the Working Party on the Accession of Estonia to the World Trade Organization, WT/ACC/EST/28 (9 April 1999), para. 107. Estonia joined.

${ }^{70}$ During the pre-WTO era, the issue of becoming a party to the optional Tokyo Round Codes was sometimes discussed during GATT accessions. See, e.g., Report of the Working Party on the Accession of Venezuela, GATT Doc. L/6696 (29 June 1990), para. 89.

${ }^{71}$ Taiwan Special Exchange Agreement, supra note 64, art. VI(3).
} 
This is WTO-plus for the WTO because the WTO obligates itself to take measures satisfactory to the

IMF. $^{72}$ Another example can be found in the China Accession Protocol which establishes special monitoring obligations over ten years for the WTO General Council and 16 subsidiary bodies. ${ }^{73}$

Chart 3 addresses WTO responsibility with a Typology of Accession Obligations for the WTO as an organization.

\section{Chart 3. Typology of the WTO’s Accession Obligations}

\begin{tabular}{|l|c|}
\hline \multicolumn{1}{|c|}{ Nature of Obligation } & Example \\
\hline WTO-Plus & Taiwan Special Exchange Agreement \\
\hline WTO-Minus & None \\
\hline
\end{tabular}

I am not aware of any accession provision that reduces obligations for the WTO.

Most of what is contained in accession agreements is not really about rules, but rather about the commitments made within market access negotiations on agriculture, non-agricultural market access, services, and possibly government procurement. Such commitments, ${ }^{74}$ memorialized in accession schedules, address matters such as tariff levels and bindings, quantitative restrictions, amount of

\footnotetext{
${ }^{72}$ The issue of Special Exchange Agreements is not specifically addressed in the Agreement between the International Monetary Fund and the World Trade Organization, signed in 1996. See W/L/195, Annexes I, III and Chart I.

${ }^{73}$ China Protocol, supra note 21, Section. I.18. The Protocol also notes that the Transitional Review Mechanism is not a precondition to the recourse to other provisions of the Protocol. Id. Section I.18(3).

${ }^{74}$ These commitments become legal obligations of the new WTO member. They are not WTO "rights" opposable to other institutions. See discussion of the Mongolian experience in text accompanying supra note 44.
} 
domestic agricultural support, and agricultural export subsidies. ${ }^{75}$ Notionally, the applicant WTO member has to agree to market access commitments that are equivalent to commitments that incumbent members have made over the years. ${ }^{76}$ Yet as John Jackson has noted with respect to GATT accession, ascertaining the equivalence in value of past concessions may be an unsolvable problem. ${ }^{77}$

The inherent subjectivity in judging equivalency is one reason why standard market access negotiations cannot be characterized as WTO-plus or WTO-minus, but the more important reasons are conceptual. Recall that WTO Agreement Article XII does not contain a norm of equivalence between the market access commitments of the applicant and the prior market access commitments of incumbent members. ${ }^{78}$ Another reason is that the WTO-plus and minus concepts refer to the rules that are embedded in accession agreements that will overwrite existing WTO rules. On some issues, such as subsidy valuation, the rules in accession agreements have an analog in existing rules. On other issues, such as price controls, the rules in accession agreements go outside the boundaries of WTO law. For both old and new issues, the common thread is that the WTO-plus (and minus) language establishes rules that will differ from the WTO law that would otherwise apply. Thus, these provisions are normatively different from market access commitments such as tariff levels, where one might expect that no two countries would make identical commitments.

\footnotetext{
${ }^{75}$ In the GATT-era, at least one Protocol of Accession contained quantitative commitments by the acceding country as to how much it would expand its imports. In 1967, Poland agreed to increase the total value of its imports from GATT parties by not less than seven percent per annum. Protocol for the Accession of Poland, GATT, BISD 15S/46, para. 9 \& Annex B, para. 1.

${ }^{76}$ See the point made by Curzon in text accompanying supra note 7 . Note, however, that market access accession negotiations are not necessarily perceived as fully retrospective. Newly acceded WTO members tend to argue that they should be able to sit out new tariff negotiations because they have already given to the cause. See, e.g., Daniel Pruzin, Saudis Rule Out Further Market Access Concessions on Manufactured Goods, BNA Daily Report for Executives, 14 September 2006, at A-1.

${ }^{77}$ JoHn H. JACKSON, WORLD TRADE AND THE LAW OF GATT 95 (1969).

${ }^{78} \mathrm{Had}$ such a norm existed, it might have been expressed either as equivalence in liberalization (i.e., effort) or equivalence in protection (i.e., level playing field). But no such norm exists.
} 
Take the example of export subsidies for agriculture. In the accession negotiations, some governments have agreed to refrain from providing any export subsidies for agriculture. Indeed, the Government of Australia now has a public position that "Australia expects new Members to eliminate agricultural export subsidies.”79 While it is true that such abstinence is not required by the Agreement on Agriculture, a zero-level commitment is a possible outcome to a negotiation and therefore fits within the framework of the Agriculture Agreement. ${ }^{80}$ Similarly, the result of market access negotiations for a particular service sector is not WTO-plus or minus because there is no legal baseline for a level of market access that is required by WTO membership.

\section{A Survey of WTO-Plus and WTO-Minus Provisions}

To my knowledge, no definitive study has been published of the rule-like provisions in WTO accession agreements. This task will surely be done at some point, and I would hope that it is done using carefully defined categories, either with the typology suggested here, or a better one in which the categories are clear and not overlapping. Although the WTO Secretariat undertakes numerous studies on a variety of topics, they have not gotten around yet to studying the WTO-plus phenomenon. The WTO Secretariat does issue a study of accession agreements that is periodically updated, ${ }^{81}$ but that study does not explicitly catalog the national commitments that go beyond current WTO law. ${ }^{82}$ Perhaps the Secretariat hesitates to address WTO-plus and minus because they are so dissonant with

\footnotetext{
${ }^{79}$ Australian Department of Foreign Affairs and Trade, "WTO Accessions and How Australia Stands to Benefit,” 2006, available at <http://www.dfat.gov.au/trade/negotiations/accession/index.html>.

${ }^{80}$ Given the excessive use of agricultural export subsidies by high-income WTO members, particularly in the European Community, one could argue that asking applicant WTO members to commit not to use such subsidies is a hypocritical, WTO-plus demand.

${ }^{81}$ Secretariat Note, supra note 20.

${ }^{82}$ See id. at 14 (calling them "terms defined by the commitment paragraph and not contained in WTO Multilateral Agreements ....”). Qin suggests that the WTO compile and publish the special obligations "in a centralized and systematic manner rather than being left in the obscure text of the working party report.” Qin, supra note 17, at 521.
} 
the egalitarian self-image of the trading system. ${ }^{83}$ Indeed, in its public education materials, the WTO Secretariat offers an unrealistic portrayal of the accession process that fails even to mention WTO-plus demands. ${ }^{84}$

Many provisions in Working Party reports are elaborate restatements of what I call the WTO’s Conformity Clause. That clause, Article XVI:4 of the WTO Agreement, declares that "Each Member shall ensure the conformity of its laws, regulations and administrative procedures with its obligations as provided in the annexed Agreements.” When an applicant country agrees to conform to WTO rules, such a commitment is neither WTO-plus nor WTO-minus. Rather, it illustrates the WTO baseline with specific implementation commitments of applicants designed to give comfort to incumbent WTO members and their stakeholders. ${ }^{85}$ To be sure, the use of accession negotiations to get the applicant government to admit the need for specific steps to achieve WTO compliance can be valuable. ${ }^{86}$

Whenever a pledge to conform sets a date different from the otherwise applicable baseline date, such a provision will be either WTO-plus or WTO-minus. Yet in some instances, because of the ambiguity in WTO transition rules, it may be indeterminate whether a tailored timetable should be categorized as a plus or a minus. In other words, in some areas, the WTO baseline is fuzzy. For example, Nepal and Cambodia were allowed several years to fully comply with the SPS Agreement.

\footnotetext{
${ }^{83}$ See, e.g., WTO Secretariat, "Small countries are NOT powerless in the WTO," available at $<$ http://www.wto.org/english/thewto_e/whatis_e/10mis_e/10m07_e.htm> ("In short, in the WTO trading system, everyone has to follow the same rules.").

${ }^{84}$ See "How to Become a Member of the WTO," supra note 15, stating that accession "Terms and conditions include commitments to observe WTO rules and disciplines upon accession and transitional periods required to make any legislative or structural changes where necessary to implement these commitments."

${ }^{85}$ The trend in WTO accession negotiations seems to be to demand that more of the key implementation by applicants be done before accession (in other words, a down payment).

${ }^{86}$ John Weeks, The External Dynamics of the WTO Dispute Settlement Understanding: An Initial Analysis of its Impact on Trade Relations and Trade Negotiations, in INTER-GOVERNMENTAL TRADE Dispute SetTlement: Multilateral and Regional Approaches 75, 96 (Julio Lacarte \& Jaime Granados eds., 2004).
} 
In view of the new accession guidelines for least developed countries discussed above, is that a WTOplus, WTO-minus, or neither?

Sometimes it is difficult to tell from the language of the Accession Working Party Reports whether the applicant government has made a WTO-plus commitment. The term "WTO-plus” is never used nor does the accession Report state that the applicant has agreed to an individualized WTO rule. Rather, the language used in the Report describes what the applicant government says it will do, and seals that up with the phrase: “The Working Party took note of this commitment.” That phrase appears several times in the first WTO accession protocol, the one with Ecuador. In my view, only one of these commitments comes close to being WTO-plus. ${ }^{87}$

In the pre-WTO era, GATT accession working party reports did not typically refer to such statements by the applicant as a “commitment.” Rather, the GATT working party reports employ the phrase: “The Working Party took note of these assurances.” ${ }^{88}$ Typically this phrase referred only to an assurance about conforming to GATT rules, not making a GATT-plus commitment.

\footnotetext{
${ }^{87}$ Report of the Working Party on the Accession of Ecuador, WT/L/77 (14 July 1995), para. 53. Ecuador was the first country to accede to the WTO. The cited commitment made by Ecuador is a statement that Ecuador "did not intend" to extend its price setting policy beyond the pharmaceutical sector. The issue of price setting is certainly WTO-plus because there are no WTO rules on that matter. But because Ecuador has only stated its intention, I doubt that this provision has enforceability.

${ }^{88}$ Accession of Guatemala, Report of the Working Party, GATT, BISD 38S/3, para. 31. Some GATT working party reports (e.g., Morocco) did not contain this phrase.
} 


\section{Applicant WTO-Plus}

Using the suggested typology, one can see many applicant WTO-plus commitments to the WTO (and indirectly to its membership). To be considered here as WTO-plus, the working party must have taken note of the commitment. ${ }^{89}$ Some examples are:

\section{Industrial Policy}

--Saudi Arabia committed that its government's pricing policy was that economic operators supplying natural gas liquids to industrial users would fully recover their costs and make a profit. ${ }^{90}$

--Moldova committed to reduce the use of price controls in its economy. ${ }^{91}$

--China committed to removing the 50 percent foreign equity limit for joint ventures in the motor vehicle engine industry. ${ }^{92}$

--China committed that within three years, "all enterprises in China shall have the right to trade in all goods throughout the customs territory of China, except for those goods listed in Annex 2A [of the Protocol] which continue to be subject to state trading in accordance with the Protocol. Such right to trade shall be the right to import and export goods."93

\footnotetext{
${ }^{89}$ Sometimes the applicant states a policy and the Working Party does not "take note" of the commitment. I do not characterize such statements as applicant WTO-plus. For example, Saudi Arabia stated that it lifted its ban on mobile phone with digital cameras. Report of the Working Party on the Accession of the Kingdom of Saudi Arabia to the World Trade Organization, WT/ACC/SAU/61 (1 November 2005), para. 157(x). In my view, WTO law permits a government to ban mobile phones with digital cameras.

${ }^{90}$ Report of the Saudi Working Party, supra note 89, para. 33 (emphasis added).

${ }^{91}$ Report of the Working Party on the Accession of Moldova, WT/ACC/MOL/37 (11 January 2001), para. 34. Compare GATT art. III:9.
}

${ }^{92}$ Report of the Working Party on the Accession of China, WT/ACC/CHN/39 (1 October 2001), para. 207. Note that a foreign equity limitation regarding commercial presence of a service provider would normally be included in a GATS schedule and thus would not be WTO-plus as defined here.

${ }^{93}$ China Protocol, supra note 21, Section I.5.1 (Right to Trade). What makes this discipline especially interesting is that WTO rules generally do not recognize or accord any substantive national law rights vertically downward from a government to domestic enterprises within a country. If the Protocol is perceived as according rights under international law to all enterprises within China, that sort of provision would be unique in international trade law as a substantive economic human right. In recent discussions in the WTO Committee on Market Access, the U.S. government has questioned whether China is keeping its commitment regarding the importation of publications. After the Chinese representative averred that China had a "right” under GATT Article XX to protect its public morals and public interest, the U.S. government asked China to explain the relevance of GATT Article XX to the Accession Protocol. WTO. Doc. G/MA/78, para. 1 (18 September 2006). 
--China committed to giving national treatment to foreign direct investors in China with respect to the purchase of goods and services and with respect to pricing of goods and services provided by public enterprises (e.g., energy). ${ }^{94}$

--China committed that state-owned and state-invested enterprises would make purchases and sales based solely on commercial considerations. ${ }^{95}$

\section{Health and Environmental Regulation}

--China committed to provide six years of exclusivity for the use of data to obtain product approval of pharmaceutical and agricultural products which utilize new chemical entities irrespective of whether they are patent-protected. ${ }^{96}$

--the Kyrgyz Republic committed not to require additional certification for products which have been certified as safe for human use by recognized foreign or international bodies. ${ }^{97}$

--Taiwan committed to permit advertising for alcoholic beverages in all media subject to regulation in relation to the content and timing of advertising. ${ }^{98}$

--Jordan committed to applying the SPS Agreement "in a least trade distortive manner from the date of accession without recourse to any transition period."99

\section{Tax Policy}

--Estonia committed to apply national treatment with respect to direct taxation. ${ }^{100}$

\footnotetext{
${ }^{94}$ China Protocol, supra note 21, Section I.3. Compare WTO Agreement on Trade-Related Investment Measures (TRIMS).

${ }^{95}$ Report of the China Working Party, supra note 92, paras. 46, 172.

${ }^{96}$ Report of the China Working Party, supra note 92, para. 284. Compare TRIPS art. 39.3.

${ }^{97}$ Report of the Working Party on the Accession of the Kyrgyz Republic, WT/ACC/KGZ/26 (31 July 1998), para. 103. Compare SPS Agreement art. 3.3 \& Agreement on Technical Barriers to Trade (TBT Agreement), art. 2.4.

${ }^{98}$ Report of the Working Party on the Accession of the Separate Customs Territory of Taiwan, Penghu, Kinmen and Matsu, WT/TPKM/18 (5 October 2001), para. 21.

${ }^{99}$ Report of the Working Party on the Accession of the Hashemite Kingdom of Jordan, WT/ACC/JOR/33 (3 December 1999), para. 151. This is a double WTO-plus provision which adds a least-trade-distortive requirement to all SPS rules and which denies Jordan whatever transition period is available in the ambiguous SPS Agreement Article 14. The SPS Agreement does not contain such a least-trade-distortive requirement (see SPS Article 5.6, footnote 3).

${ }^{100}$ Report of the Estonia Working Party, supra note 69, para. 15. Compare GATT art. III.
} 
Financial Policy

--Taiwan committed: (1) to endeavour to direct its economic and financial policies toward the objective of fostering sustained, non-inflationary economic growth with macroeconomic stability, and (2) to permit exchange rates to reflect underlying economic and financial conditions. ${ }^{101}$

--Taiwan committed not to impose restrictions on the making of payments and transfers related to current account transactions "without the approval of the WTO.”102

--Saudi Arabia committed that with regard to regulation of the insurance sector, it would undertake regulatory reforms by May 2006 that would be consistent with internationally recognized insurance industry standards and principles, including the standards of the International Association of Insurance Supervisors, the financial services transparency code of the IMF, and the OECD's "Detailed Principles for the Regulation and Supervision of Insurance Markets in Emerging Economies.”, "103

\section{Foreign Policy}

--Saudi Arabia "confirmed"104 that "the application of secondary and tertiary boycotts" (i.e., directed against firms that do business with Israel) "had been terminated in practice and in law."105

${ }^{101}$ Taiwan Special Exchange Agreement, supra note 64, art. I(2)(i) and (ii). Not only is this an applicant WTO-plus discipline, but it also appears to be IMF-plus. Compare Articles of Agreement of the International Monetary Fund, 22 July 1944, 2 UNTS 39, art. IV(1)(i), as amended, available at $<$ http://www.imf.org/external/about.htm>.

${ }^{102}$ Taiwan Special Exchange Agreement, supra note 64, art. II(1). This is an example of a situation in which a decision of a WTO body might be scrutinized by a panel to see whether the WTO has in fact given approval. If there is an implied obligation of the WTO to decide whether to approve, that constitutes a new WTO WTO-Plus obligation.

${ }^{103}$ Report of the Saudi Working Party, supra note 89, para. 296.

${ }^{104}$ Although this information is not couched as a commitment by the Saudi Arabia, the sentence that follows in the Report of the Working Party states that "The Working Party took note of this commitment.” Report of the Saudi Working Party, supra note 89, para. 103. Thus, one can reasonably infer that Saudi Arabia recognized that WTO members would perceive its statement as a legal commitment to not reinstate the boycott. Should such a reinstatement occur, there would be a cause of action against Saudi Arabia without having to show that the boycott itself constitutes a violation of the WTO Agreement.

${ }^{105}$ Report of the Saudi Working Party, supra note 89, para. 103. If the boycott is a WTO violation, then this commitment is not WTO-plus. For a discussion of the WTO legality of the boycott, see Eugene Kontorovich, The Arab League Boycott and WTO Accession: Can Foreign Policy Excuse Discriminatory Sanctions, 4 CHI. J. INT’L L. 283 (2003). 


\section{Trade Policy}

--Latvia committed to nullify measures taken by subnational authorities that are in conflict with the WTO Agreement. ${ }^{106}$

--China committed to apply to all imports of wood and paper products the same rates of duty that it applies in a free trade area. ${ }^{107}$

--China committed to not invoking three provisions applying to developing countries in the Agreement on Subsidies and Countervailing Measures (SCM Agreement) that provide for "special and differential treatment."108

--China committed that "Once the international harmonization of non-preferential rules of origin was concluded, China would fully adopt and apply the internationally harmonized nonpreferential rules of origin.",109

--China committed to withhold enforcement of the terms of any contract providing local content or export performance requirements. ${ }^{110}$

--Saudi Arabia committed to not imposing export duties on iron and steel scrap. ${ }^{111}$

\section{Transparency and Due Process}

--Armenia committed to publish all laws, regulations or other measures relating to trade in goods and services at least two weeks prior to implementation. ${ }^{112}$

${ }^{106}$ Report of the Working Party on the Accession of Latvia to the World Trade Organization, WT/ACC/LVA/32 (30 September 1998), para. 30. Compare to GATT art. XXIV:12 and GATS art. I:3(a) which do not contain an obligation to nullify.

${ }^{107}$ Report of the China Working Party, supra note 92, para. 91. This is more than a GATT binding because it cannot be renegotiated under GATT art. XXVIII.

${ }^{108}$ Id. para. 171.

${ }^{109}$ Id. para. 100. The reference is to the international negotiations spawned by Article 9 of the WTO Agreement on Rules of Origin. Article 9.4 further states that after the negotiations are completed, the results shall be established in an Annex to the Agreement "as an integral part" of this Agreement and that a timeframe for the entry into force shall be established. China would not benefit from whatever phaseouts are negotiated under that timeframe and might have to comply upon signing rather than the entry into force.

${ }^{110}$ Report of the China Working Party, supra note 92, para. 203.

${ }^{111}$ Report of the Saudi Working Party, supra note 89, para. 184. If it were merely a tariff binding, such a commitment could avoid being categorized as WTO-plus.

${ }^{112}$ Report of the Working Party on the Accession of Armenia, WT/ACC/ARM/23 (26 November 2002), para. 215. Compare GATS, art. III:1 and TBT Agreement, art. 2.9.1. 
--China committed that it would maintain tribunals for the prompt review of all administrative actions relating to trade in services and that such tribunals would be impartial and independent of the administering agency. ${ }^{113}$ China also guaranteed a right of individuals or enterprises to appeal to a judicial body. ${ }^{114}$

--China committed to publishing an official journal dedicated to the publication of laws and regulations pertaining to or affecting trade in goods, services, TRIPS or the control of foreign exchange and, after publication .... committed to provide a reasonable period for comment before such measures are implemented ....

\section{Legal Status of WTO Agreement in National Courts}

--Estonia committed that if its laws were found to “contradict” international treaties, including the WTO Agreement, the provision of the international treaty would apply. ${ }^{116}$

--Jordan committed the same. ${ }^{117}$

The listing above is illustrative of the WTO-plus phenomenon for the applicant. The listing is not intended to be exhaustive, but contains examples of the most far-reaching commitments. All of the commitments listed are WTO-plus in the sense of being obligations that go beyond the WTO rules (baseline) that would otherwise prevail.

The WTO-plus topics most often addressed are direct taxes, the regulation of investment, prices, energy, and currency, transparency, and administrative and judicial review. Note that unlike recent U.S. free trade agreements which contain many intellectual property rights commitments that go

${ }^{113}$ China Protocol, supra note 21, Section I.2.D.1. Compare GATS art. VI:2.

${ }^{114}$ China Protocol, supra note 21, Section I.2.D.2. Compare GATS art. VI:2 and GATT art. X:3(a), (b).

${ }^{115}$ China Protocol, supra note 21, Section I.2.C.2.

${ }^{116}$ Report of the Report of the Estonia Working Party, supra note 69, para. 43. This is forward commitment not just for WTO law but for all international treaties and may possibly include human rights treaties.

${ }^{117}$ Report of the Jordan Working Party, supra note 99, para. 43. It is interesting to note that the United States has never given this commitment in international negotiations and instead follows the later-intime rule with respect to conflicts between a treaty and a federal statute. See Head Money Cases, 112 U.S. 580, 599 (1884) in general and 19 USCS §3512(a)(1) for the WTO. 
beyond WTO rules, ${ }^{118}$ WTO accession agreements generally do not add obligations on top of the TRIPS Agreement (i.e., the WTO Agreement on the Trade-Related Aspects of Intellectual Property Rights) beyond transparency and judicial enforcement. Instead, incumbent members seem to be focusing their bargaining leverage on regulatory changes to facilitate market access. So far, the leverage has not been used to seek WTO-plus commitments regarding, environment, human rights, or other domestic policies. Yet such linkage may have occurred informally. ${ }^{119}$

Applicants consent to such provisions as part of the price for being allowed to join the WTO. As the WTO Secretariat points out, no country is forced to join to the WTO. ${ }^{120}$ Yet the reality is that because membership in international organizations is essential to modern sovereignty, a country wanting to gain a seat at the WTO has to consent to the WTO-plus commitments. Sometimes the applicant government may consent reluctantly. Sometimes it may consent wholeheartedly because its policymakers may be happy to embrace WTO-plus as a way of locking in the policies favored by the regime and elites in power. Because WTO entry negotiations are always carried out by national authorities, WTO-plus provisions can be a potent means of enhancing the centralization of economic policymaking authority. ${ }^{121}$

Governments applying to join the WTO often protest the demand for WTO-plus provisions, but they almost always cave in. When a government balks, the accession can be put on hold (e.g., Vanuatu). Sometimes the applicant government has succeeded in asserting the principle that it will not

\footnotetext{
${ }^{118}$ This practice is discussed and criticized in the 2005 U.N. HuMAN DEVELOPMENT REPORT, at 137. ${ }^{119}$ See, e.g., David Filipov, Putin Promises to Ratify Kyoto Treaty Moves Paves the Way for Russia to Join World Trade Group, Boston GloBe, 22 May 2004, at A6. This was a rather public side deal that Russia fulfilled.

${ }^{120}$ See WTO Secretariat, "Weaker countries do have a choice, they are NOT forced to join the WTO," available at $<$ http://www.wto.org/english/thewto_e/whatis_e/10mis_e/10m09_e.htm>.

${ }^{121}$ See Rolf J. Langhammer \& Matthias Lücke, WTO Accession Issues, 22 THE WoRLD EconOMY 837, 866 (1999).
} 
agree to certain WTO-plus demands. For example, in 1996, Bulgaria affirmed its intention to insure transparency, but then went on to bravely declare:

This was not to be regarded as a basis for the imposition of specific obligations under the Agreements or as a basis for the adoption of new special policy commitments. Bulgaria could not undertake commitments exceeding the regular membership obligations. ${ }^{122}$

One wonders how the political dynamics of accession would have been different if all acceding countries had united in solidarity on the principle of not undertaking commitments exceeding the regular membership obligations.

Unfortunately, the WTO has erected a barrier to the free flow of information about accession by imposing a cloak of secrecy over accession negotiations. ${ }^{123}$ This secrecy hinders possible cooperative efforts between governments and civil society to better outcomes in the accession process. For example, the ongoing WTO accession negotiation with the Russian Federation is of interest to people around the globe. Nevertheless, the most recent Russian accession documentation available on the WTO website is dated December 1997. This lack of WTO transparency is shameful in my view. Such secrecy is not mandated by Article XII. Given the slothful pace of the accession process at the WTO, any argument that secrecy is essential to the efficiency of the accession process would seem implausible.

\footnotetext{
${ }^{122}$ Report of the Working Party on the Accession of Bulgaria, WT/ACC/BGR/23 (20 September 1996), para. 24. When the WTO General Council approved Bulgaria’s accession, Bulgaria stoically declared that it had agreed to implement all WTO agreements "without any transition period notwithstanding its financial and structural difficulties ....” WTO General Council, Minutes, WT/GC/M/14, at 3.

${ }^{123}$ In that regard, it is interesting to recall a major address in 1998 by then WTO Director-General Renato Ruggiero who declared:
}

To characterize the WTO - as we have read recently - as an organization that "refuses to reveal its deliberations to the public, or be held responsible for the social, political and environmental costs of its decisions" is a false representation. No one can claim it.

Renato Ruggiero, “A Global System for the Next Fifty Years,” 30 October 1998, available at $<$ http://www.wto.org/english/news_e/sprr_e/chat_e.htm>. 
Applicant WTO-Minus

Applicant WTO-minus provisions are less frequent than Applicant WTO-plus. With WTOminus, the applicant country is permitted to join the WTO without having to immediately conform to an inconvenient WTO discipline. In WTO accessions, such derogations are time-limited. For example:

--Lithuania began its WTO membership on May 31, 2001, but was given until December 31, 2005 to bring its excise taxes on beer and mead into conformity with GATT Article III. ${ }^{124}$

--Taiwan was given two years after accession to eliminate the import ban on passenger cars equipped with diesel engines. ${ }^{125}$

--Ecuador was given seven years to phase out its “price band system” in order to comply with the WTO Agreement on Agriculture. ${ }^{126}$

Note that applicant WTO-minus is a rule applying to a particular WTO member. Acceding WTO members also enjoy the benefit of the numerous provisions in WTO Agreements that reduce obligations of developing country members (so called “Special and Differential Treatment”). ${ }^{127}$

\section{Incumbent WTO-Minus}

New WTO-minus obligations can also be generated for incumbent WTO members. ${ }^{128}$ Recall that incumbent WTO-minus provisions are reduced obligations below those contained in WTO

\footnotetext{
${ }^{124}$ Report of the Working Party on the Accession of Lithuania to the World Trade Organization, WT/ACC/LTU/52 (7 November 2000), para. 66.

${ }^{125}$ Report of the Taiwan Working Party, supra note 98, para. 71.

${ }^{126}$ Report of the Ecuador Working Party, supra note 87, paras. 47-48. In Chile - Price Band System, the complainant Argentina pointed to this accession term as showing by parallel inference that Chile's price band system was a violation. The panel held that it did not have enough information to take this argument into account. Panel Report, Chile - Price Band System and Safeguard Measures Relating to Certain Agricultural Products, WT/DS207/R, adopted 23 October 2002, as modified by Appellate Body Report, WT/DS207/AB/R, DSR 2002:VIII, 3127, para. 7.79 \& n. 655.
}

${ }^{127}$ See, e.g., "Special and Differential Treatment for Least-Developed Countries," Note by the Secretariat, WT/COMTD/W/135 (5 October 2004). 
multilateral agreements. ${ }^{129}$ Such provisions are sought to assuage protectionist fears by incumbent members. In effect, such provisions deny unconditional most-favored-nation treatment to applicants when they enter the WTO. Some examples are:

--The China Protocol contains a number of "Reservations by WTO Members"130 which grandfather ongoing trade discrimination against China. ${ }^{131}$ For example, the accession terms negotiated by the WTO state that listed Mexican antidumping measures may persist for six years and "shall not be subject to the provisions of either the WTO Agreement or the anti-dumping provisions of this Protocol.",132

--The China Protocol establishes the possibility of imposing product-specific safeguards against China in response to market disruption. ${ }^{133}$ This provision contains a weaker discipline that the normal one in the Agreement on Safeguards.

--The China Protocol provides laxer rules that supersede the normal WTO disciplines regarding price comparability in determining subsidies and dumping (i.e., non-market economy status) for trade with China. ${ }^{134}$ Some of these dispensations expire after 15 years and some are permanent. ${ }^{135}$

\footnotetext{
${ }^{128}$ It is interesting to note that in presenting the China accession negotiation to the public, the European Commission glossed over the fact that the accession agreement reduces obligations of the European Union below the baseline. The Commission called China's Protocol as "A one-way market opening process" and explains that "the process consisted in the WTO Membership securing 'concessions' or market opening improvements from China, without themselves altering their obligations within the WTO.” European Commission, “Overview of the Terms of China’s Accession to WTO,” http://trade.ec.europa.eu/doclib/html/111955.htm (last visited 1 November 2006) and on file with author.

${ }^{129}$ They are reduced obligations to acceding members below the baseline obligations to members generally. They are not reduced in the sense that the acceding country is put in a worse position than it was before its accession.

${ }^{130}$ China Protocol, supra note 21, Section I.17 \& Annex 7.

${ }^{131}$ It is interesting to recall that Article XVI:5 of the WTO Agreement states that "No reservations may be made in respect of any provision of this Agreement." The Reservations in the China Protocol are not typical unilateral treaty reservations, but rather a list of opt-outs agreed by the parties to the China Accession Protocol.

${ }^{132}$ China Protocol, supra note 21 . In other words, the WTO has given six years of immunity to Mexico for its ongoing antidumping actions.

${ }^{133}$ China Protocol, supra note 21, Section I.16. This protectionist opportunity lasts for 12 years and is already in use. Consultations are required before a safeguard can be imposed. See, e.g., Taiwan's request for consultations regarding toweling, G/SG/N/16/TPKM/1 (27 April 2006).

${ }^{134}$ China Protocol, supra note 21, Section I.15.
} 
--The China Working Party report provides special rules regarding trade in textiles and clothing wherein an incumbent WTO member may impose specified quantitative restrictions on China if: (1) the member believes that Chinese products "threaten the orderly development of trade" in such products and (2) China has not agreed to impose comparable export restraints to those specified. ${ }^{136}$

Note that incumbent WTO-minus provisions cannot be justified as a partial non-application of the WTO Agreement because the options available under Article XIII are binary—either application or non-application.

\section{The Legal Basis for Enforcing WTO-Plus and Minus Provisions}

The typology in Part II show the many types of commitments that could be at issue in WTO dispute settlement. The most likely procedural posture in litigation would be for an incumbent WTO member to use an accession provision as a sword. In other words, the incumbent would claim that the acceded country has not implemented its accession commitment and would seek dispute settlement based on that commitment. This has happened in the new Auto Parts case being brought against China by Canada, the EC, and the United States. Another possible procedural posture is for the acceded WTO member to use one of its WTO-minus provisions as a shield (i.e., defense) against a claim of

${ }^{135}$ Julia Ya Qin, WTO Regulation of Subsidies to State-Owned Enterprises (SOEs) - A Critical Appraisal of the China Accession Protocol, 7 J. InT’L Econ. L. 863, 903-04, 907, 918 (2004) (suggesting that the Protocol be amended to institute a time limit). The legal requirement for amending an accession protocol is unclear. Is it Article X or XII (or both) of the WTO Agreement?

${ }^{136}$ Report of the China Working Party, supra note 92, para. 242. This protectionist opportunity lasts for seven years. In addition to being a WTO-minus opportunity for incumbents, it is also notionally WTO-minus for China in permitting it to yield to foreign demands by adopting export restraints that would otherwise be a WTO violation. At this time, China has agreed to restrain certain textile and apparel exports to Brazil, the EC, South Africa, and the United States. If any other WTO member did this, it would be a violation of the Agreement on Safeguards, art. 11.1(b). But for China, its accession obligations may override its obligations under the Agreement on Safeguards. In addition, one could argue that any special safeguard provided for in an accession protocol does not come within the scope of the Agreement on Safeguards, and therefore does not give rise to a WTO-minus. See Agreement on Safeguards, art. 11.1(c) stating that this Agreement does not apply to measures taken pursuant to protocols and agreements or arrangements concluded "within the framework of GATT 1994." Whether a WTO Accession Protocol qualifies as a protocol within the GATT framework presents an interesting question. 
violation. That has not happened. Another possible procedural posture is for the acceded member to claim that a measure of an incumbent member violates the WTO Agreement and is contrary to the WTO-minus provisions in an accession agreement. Such a dispute would probably center around the contested WTO-minus language with incumbent country seeing it as a shield and the acceded country seeing it as a sword. ${ }^{137}$ Additional procedural postures are imaginable. ${ }^{138}$

The assumption within the trading system is that the DSU will be available in such situations. The only commentator I am aware of who may have questioned this conclusion is Antonio Parenti, and his position, written in the early years of the WTO, is imprecise. On the one hand, he says unqualifyingly that an accession protocol "will be subject to the discipline of the Dispute Settlement Understanding." ${ }^{139}$ On the other hand, he asserts that WTO Agreement Article XII "needs to be interpreted in a teleological way" and that "the terms of accession of one country cannot go beyond the requirements imposed by the [WTO] Agreement itself, which is the scheduling of commitments in the market access sphere and the assurance of the respect of the various parts that form the WTO Agreement." ${ }^{140}$ He goes on to say that accession to the WTO "cannot be made conditional on the acceptance by the acceding country of altered terms, or the non application vis-á-vis itself of any WTO

${ }^{137}$ See Huang, supra note 61, at 139-40 (footnote omitted) who discusses the tension between "the right of a WTO Member under paragraph 242 [the selective safeguard in the China accession] to impose quantitative restrictions ... . [and] the corresponding right of China under paragraph 242 . . . to prevent abuse of this paragraph." Huang's interesting treatment of the clash of rights shows the conceptual entrapment that can result from perceiving WTO accession obligations as rights.

${ }^{138}$ Because an accession protocol is an agreement between the WTO and the acceding member, the WTO itself would have an interest in lodging a case if an agreement made with it were not fulfilled. The WTO would probably not be able to bring the case in the DSB, however, because there is no provision in the DSU for a WTO complaint against a member. See the holding of the Appellate Body discussed in supra note 23. Yet if the acceding member had no objection to being challenged by the WTO and if other members were to go along, it might be possible for the DSB to establish a panel by consensus.

${ }^{139}$ Antonio Parenti, Accession to the World Trade Organisation: A Legal Analysis, 27(2) LEGAL IssUES of ECON. InTEGRATION 141, 155 (2000). At the time that he wrote the article, Parenti worked on trade issues in the European Commission.

${ }^{140} I d$. at 152 . 
Agreement.” ${ }^{141}$ Furthermore, he states an “Any alteration to the obligations of a WTO Member” is possible only through a WTO amendment or other specified procedures, and thus that "An alteration occurring in case of an accession would therefore not be consistent with WTO rules.”142 ${ }^{\text {Parenti’s }}$ interesting analysis ends there and he does not draw any conclusions about what should happen when an accession agreement is inconsistent with WTO rules as he sees them. ${ }^{143}$ Parenti does not specifically argue that an incumbent WTO member would lack a cause of action regarding certain kinds of accession disciplines.

In taking note of Parenti's intriguing comments, I am not endorsing them. My position is that when stated as an obligation, the negotiated terms in accession agreements are enforceable in the WTO. What I am seeking to clarify in this article is why they are enforceable.

Here it may be useful to reiterate a point made earlier: The focus of this article is the legality and enforceability of WTO-plus and WTO-minus commitments. The other commitments in an accession agreement which are included in the various schedules are clearly enforceable because they are annexed to the applicable provisions in the GATT, GATS, and other WTO agreements. If everything in the Accession Protocol were actually included in such schedules, there would not be any legal puzzle left to solve. The reason why there is a puzzle is that many accession terms are not scheduled, but rather are written into the text of an accession protocol or are commitments made in the report of the working party that are incorporated by reference into that protocol. ${ }^{144}$

\footnotetext{
${ }^{141}$ Id. at $155-56$.

${ }^{142} I d$. at 156 .
}

${ }^{143}$ Parenti also argues that international law imposes limits on the freedom of incumbent WTO members to oppose an accession request for reasons unrelated to the conditions for membership set by the WTO Agreement. Id. at 142-44.

${ }^{144}$ See Standard Protocol, supra note 20, para. 2. My study of the schedules of acceding countries was limited because they posted on the WTO website in an arcane, compressed format that was unreadable to my computers. The WTO does have useable government schedules in the CTS database, but does not give the public access to this information. 
Protocols of Accession do not state that they are enforceable in WTO dispute settlement. ${ }^{145}$ Given the centricity of dispute settlement in the WTO, one should assume that the drafters of accession protocols were inattentive whether there would be dispute settlement available regarding the provisions in that agreement. ${ }^{146}$ Therefore, I posit that the Protocol of Accession does not include language referencing the DSU because incumbent members assumed that recourse to DSB would be available. Suppose that the Standard Protocol had included language stating that the DSU applied. In my view, that would not solve the problem. The mere inclusion of a statement in a Protocol that the DSU applies is hardly enough to confer jurisdiction.

The WTO General Council may have competence to conclude an international agreement ${ }^{147}$ with another subject of international law, but the General Council does not have competence to confer new jurisdiction on the DSB. Imagine that the WTO General Council were to negotiate a Protocol (or other agreement) with the International Labour Organization regarding “Worker Rights in Trade” and

\footnotetext{
${ }^{145}$ See the Standard Protocol excerpted above as well as the China Protocol. Two tiny exceptions should be noted however. First, the Annex to Taiwan's Protocol contains the Special Exchange Agreement, and that Agreement states that the DSU shall apply to disputes under that Agreement. Taiwan Special Exchange Agreement, supra note 64, art. VI:4. An analyst could infer that the mention of enforceability there but not in the Protocol itself implies that the Protocol itself is unenforceable. I do not draw that inference however. Second, the China Working Party Report committed that "WTO Members would have recourse to WTO dispute settlement to ensure implementation of all commitments in China’s GATS schedule.” China Working Party, supra note 92, para. 320. I would not infer that without this commitment, dispute settlement would have been unavailable.

${ }^{146}$ Note that the drafters of the WTO Information Technology Agreement were attentive to the possible need for dispute settlement and stated that participants understood that GATT Article XXIII would be available. Ministerial Declaration on Trade in Information Technology Products, WT/MIN(96)/16, Annex, para. 6 (13 December 1996).

${ }^{147}$ Recall that Accession Protocols are formally agreements between the WTO and the applicant country and are registered in accordance with the provisions of Article 102 of the U.N. Charter.
} 
declares in it that disputes between governments could be settled in the DSU. ${ }^{148}$ I assume that most WTO experts would find that the General Council has no competence to confer such jurisdiction on WTO panels absent an amendment to the WTO Agreement. Yet if that finding is justified, then how can the WTO General Council (or Ministerial Conference) give the DSB jurisdiction over an Accession Protocol merely by including a jurisdictional provision within the Protocol? Put in another way, the parties to an Accession Protocol are not necessarily free to choose whatever dispute settlement they want because there are mandatory structural limits in the WTO Agreement as to when the DSU can apply.

What Protocols of Accession do state is that "The Protocol ... shall be an integral part of the WTO Agreement."149 This clause-let me call it the "Integral Clause”- has been pointed to by several commentators as the explanation for why commitments in the Protocol are enforceable through the DSU. In my view, however, that explanation cannot be right and demonstrates the classic petitio principii fallacy_assuming what one seeks to prove.

The Integral Clause cannot justify enforceability for the reasons noted above in my example of the WTO-ILO Protocol. That is, neither the WTO Ministerial Conference nor the General Council has a general competence to conclude a Protocol with another subject of international law and thereby

\footnotetext{
${ }^{148}$ Some authority exists for this in Article V:1 of the WTO Agreement which authorizes the General Council to make appropriate arrangements for effective cooperation with other intergovernmental organizations. The WTO has numerous agreements with other international organizations-for example, the Agreement between the International Bank for Reconstruction and Development, the International Development Association and the World Trade Organization, W/L/195, Annexes II, IV (18 November 1996) and the Agreement between the World Intellectual Property Organization and the World Trade Organization, 22 December 1995, WTO Doc. IP/C/6. Neither of these Agreements provide for dispute settlement. As far as I know, none of the WTO Agreements or Memoranda of Understanding with other organizations provide for dispute settlement. The WTO also has a Headquarters Agreement with Switzerland (WT/GC/1) pursuant to WTO Agreement Article VIII:5, but the dispute settlement tribunal is ad hoc binding arbitration, not the DSB. See Headquarters Agreement, WT/GC/1, WTO, BISD 1995, art. 48, at 59. (The President of the International Court of Justice is to appoint the third member of the tribunal in the event of a disagreement.) The Headquarters Agreement contains secret Appendixes and Annexes not published by the WTO.

${ }^{149}$ Standard Protocol, supra note 20, para. 2.
} 
make that Protocol part of the WTO Agreement through the Integral Clause. ${ }^{150}$ In my view, any change in the WTO Agreement sought by the Ministerial Conference has to be effectuated through the procedures in WTO Agreement Article X (Amendments). One should also note that the DSU does not have an open-ended “Coverage and Application” clause stating that it can be applied to any future agreement that the General Council characterizes as an "integral part” of the WTO Agreement.

The inclusion of the Integral Clause in every Accession Protocol must have been for a reason and I would guess that it was done with the aim of enforceability in mind. Early accession negotiators may have been seeking to make a Protocol a self-enacting amendment to the WTO. No WTO public records have come to my attention that shed light on the intended meaning of the Integral Clause. The New Shorter Oxford English Dictionary defines “integral” as “necessary to the completeness or integrity of the whole, not attached." ${ }^{151}$ Note that the Integral Clause was not included in the Standard GATT Accession Protocol. ${ }^{152}$

The idea of positioning the accession protocol within the WTO Agreement is probably that the protocol thereby gains the hierarchical status of the WTO Agreement which is superior to all of the Multilateral Trade Agreements in Annexes 1-3 of the WTO Agreement. ${ }^{153}$ In other words, in the event of a conflict between the Agreement on Safeguards and an accession protocol, the latter would prevail.

\footnotetext{
${ }^{150}$ This statement is a logical conclusion from legal hierarchy. In general, one should not assume that an entity created by positive law would have inherent authority to change the organic law that created it. For example, the World Health Organization cannot rewrite its treaty mandate. Prescinding the idea of constitutional moments, higher law in general can only be amended through the means prescribed in the higher law.

${ }^{151}$ The New Shorter OXFord English Dictionary On Historical Principles 1386 (Lesley Brown ed., 1993). This is the most suitable of several definitions.

${ }^{152}$ GuIDE TO GATT LAW AND PRACTICE, supra note 33, at 1021.

${ }^{153}$ WTO Agreement arts. II:2, XVI:3.
} 
Some commentators, such as Julia Qin, have suggested that this clause transforms accession protocols into one of the WTO “covered agreements”154 thereby confers jurisdiction of the DSB over accession protocols. ${ }^{155}$ The use of the Integral clause certainly suggests that the WTO Ministerial Conference intended to make an Accession Protocol a central aspect of the WTO Agreement, and one could argue that if an Accession Protocol is a "part” of the WTO Agreement, which is itself “covered," $" 156$ then the Protocol itself has to be covered.

Nevertheless, the same concerns offered above about bootstrapping apply with equal force to this flexible view of the term “covered agreement.” In my opinion, the Ministerial Conference lacks the competence to add to the covered agreements outside of the WTO amendment process. ${ }^{157}$ DSU Article 1.1 states that the “covered agreements” are those listed in Appendix 1 of the DSU and Appendix 1 does not list any accession protocols. Nor does Appendix 1 say that the covered agreements will also include any additional "part” of the WTO deemed “integral” by the Ministerial Conference. It is interesting to note that several accession working party reports contain comments by

\footnotetext{
${ }^{154}$ The covered agreements are defined as the agreements listed in DSU Appendix 1. These include the WTO Agreement itself and its Annexes 1, 2, and 4. Annex 3 is a multilateral trade agreement but not a covered agreement. The plurilateral agreements in Annex 4 can be covered agreements even though they are not multilateral trade agreements.

${ }^{155}$ Qin, supra note 17 , at 508-09.

${ }^{156}$ DSU Appendix 1.

${ }^{157}$ The same issue arises to some extent with waivers available under WTO Agreement Article IX:3 and interpretations available under Article IX:2. Are waivers and interpretations covered agreements? In the EC - Bananas III case, the Appellate Body engaged in interpretation of the Lomé Waiver without discussing whether it is a "covered agreement.” Appellate Body Report, EC - Bananas III, supra note 41, para. 168. During the GATT era dispute settlement, there were cases in which a waiver was invoked as a defense. GUIDE TO GATT LAW AND PRACTICE, supra note 33, at 709-12. So far, no formal interpretation has been approved, and therefore WTO panels have not been faced with the task of interpreting an interpretation. Apropos of the need to avoid using Article XII as a backdoor amendment to the WTO Agreement, recall that Article IX:2 of the Agreement states that the authority to adopt interpretations "shall not be used in a manner that would undermine the amendment provisions in Article X.” Whether that rule is justiciable remains to be seen.
} 
the applicant suggesting that the accession protocol will be a "provision" of the WTO Agreement. ${ }^{158}$ This may show an expectation of that result by applicant countries, but I doubt that the expectations of applicant countries can add to or diminish the obligations provided in the covered agreements.

The term "integral part” does have a history in the trading system. It appears in GATT Article II:7 which states that schedules “are hereby made an integral part of Part I of this Agreement” and in GATT Article XXXIV which states that “The annexes to this Agreement are hereby made an integral part of this Agreement.” That term also exists in GATS Article XX:3 and XXIX in an analogous context. The term also appears in WTO Agreement Article II:2 which states: “The agreements and associated legal instruments included in Annexes 1, 2 and 3 (hereinafter referred to as 'Multilateral Trade Agreements') are integral parts of this Agreement, binding on all Members.” In my opinion, the Uruguay Round drafters should have included a WTO Agreement Article XII Annex for Accession Agreements. Unfortunately, they neglected to do so.

Regardless of the impressive lineage of “integral part,” there is a big difference between a provision of a treaty stating that treaty's annexes will be an integral part of the treaty, and a negotiation held after the treaty is adopted that purports to make the results an integral part of the treaty. An analogy to GATT Article II would be more relevant if Article XII of the WTO Agreement stated that any accession terms will be an "integral part” of the WTO. But Article XII does not state this. So it seems clear that simply by importing the language "integral part" from the other WTO contexts in which it appears does not itself justify using the Integral Clause to transform whatever is in an accession protocol into a WTO discipline enforceable in the DSB. Furthermore, the idea that an Integral Clause achieves enforceability is undermined by the fact that Taiwan's Protocol says that the

\footnotetext{
${ }^{158}$ For example, the Saudi Working Party report, supra note 90, states that "The representative of Saudi Arabia confirmed that the provisions of the WTO Agreement, including Saudi Arabia's Protocol, would be applied uniformly throughout Saudi Arabia's customs territory . . . .” Id. para. 88. Similar statements are included in the working party reports for Albania, Croatia, Georgia, Jordan, Lithuania, and Moldova.
} 
Special Exchange Agreement "forms an integral part of this Protocol," and yet the Exchange Agreement nevertheless includes a statement that the DSU shall apply to disputes under the Agreement. ${ }^{159}$ This wording in the Taiwan Exchange Agreement may appear because the drafters thought that merely making it an integral part of the Protocol (which is said to be an integral part of the WTO Agreement) was not enough to achieve enforceability.

It is interesting to recall that when Special Exchange Agreements were adopted in the GATT era, the language in those agreements stated that the Agreement, entered into pursuant to Article XV of the General Agreement, shall be deemed to be included within that Article.”160 This status matched and followed from the text of GATT Article XV:6 which states:

Any contracting party which is not a member of the Fund shall . . . become a member of the Fund, or, failing that, enter into a special exchange agreement with the CONTRACTING PARTIES. . . . Any special exchange agreement entered into by a contracting party under this paragraph shall thereupon become part of its obligations under this Agreement.

In retrospect, the drafters of Article XII of the WTO Agreement missed an opportunity to write in a similar sentence stating that the terms of accession of an acceding government would become an integral part of Article XII.

Some commentators have argued that an accession protocol is an amendment to the WTO, and being an amendment would be enforceable like any other amendment. For example, two distinguished commentators, Claus-Dieter Ehlermann and Lothar Ehring, have characterized accession protocols as "an amendment of the WTO Agreement because this Agreement is modified so as to cover an additional subject of international law."161 They go on to state that "Legally, the standard WTO

\footnotetext{
${ }^{159}$ Taiwan Protocol, supra note 64, para. 4; Taiwan Special Exchange Agreement, supra note 64, art. VI:4.

${ }^{160}$ See the model Special Exchange Agreement referenced in supra note 65, Article XVI:4.

${ }^{161}$ Claus-Dieter Ehlermann \& Lothar Ehring, Decision-Making in the World Trade Organization, $8 \mathrm{~J}$. INT’L ECON. L. 51, 57 (2005).
} 
Accession Protocol amends the WTO Agreement by becoming an integral part of the WTO Agreement."162

Although their analysis contains a great deal of insight, I believe that it is wrong to suggest that an accession protocol can amend the WTO Agreement. Aside from the fact that the provisions for amending the WTO are in Article X not Article XII, one should also consider that Article X states detailed rules as to how particular kinds of amendments are to be accepted by members, rules that would be evaded if Article XII could be used to amend the WTO. ${ }^{163}$

The use of the term "protocol” in "Accession Protocol” could, on first glance, appear to support the idea that an accession protocol is an amendment. After all, Protocols exist in other bodies of international law and are sometimes called a Protocol of Amendment (e.g., the Protocol of Amendment to the Charter of the Organization of American States). ${ }^{164}$ Indeed, the first multilateral trade treaty, the Prohibitions Convention of 1927, had a protocol which substantially amended the Convention. ${ }^{165}$

\footnotetext{
${ }^{162}$ Id. (footnote omitted). The footnote cites the China Accession Protocol. Ehlermann \& Ehring further state that the Accession Protocol is an agreement between the applicant and the WTO, "not an (amendment) agreement between the new and old Members.” Id.

${ }^{163}$ It is true that in current WTO practice, accession agreements are approved by consensus rather than a two-thirds vote, and consensus would be equally sufficient for the Ministerial Conference to approve an amendment to the WTO Agreement. But for an accession agreement to be fully interchangeable with a formal WTO amendment, the decision rules for each have to be equivalent not only in practice, but also de jure (i.e., the fallback voting rule). That is not the case because an accession protocol need only be approved within the WTO Ministerial Conference by a two-thirds majority of WTO members. See WTO Agreement art. XII:1. In contrast, many types of amendment to the WTO amendment have to go through a two-step process of: (1) approval in the Ministerial Conference by a two-thirds vote, plus (2) acceptance by two-thirds of the members. Id. art. X. For some amendments, the acceptance requirement is higher, either a specific acceptance by each member to be bound or full acceptance by all members. Amendments to the DSU can only be approved by consensus in the Ministerial Conference and then take effect without further acceptance.
}

\footnotetext{
${ }^{164}$ Several types of Protocols are known to international law-for example, a Protocol of signature providing for interpretation of particular provision, an Optional Protocol, a Protocol based on a Framework treaty that implements the Convention's objectives in a discrete area, a Protocol of Amendment, and a Protocol providing supplementary obligations.

${ }^{165}$ International Convention for the Abolition of Import and Export Prohibitions and Restrictions, with Protocol and Annexed Declaration, 8 November 1927, 97 LNTS 391 (not in force).
} 
Nevertheless, for the reasons outlined above, one cannot accept the idea that any time the WTO Ministerial Conference adopts something that they designate as a "protocol" that the WTO Agreement is thereby amended. For instance, I would deny that an accession protocol could validly be used to fix the DSU Articles 21 and 22 sequencing problem even though an applicant government might rationally want this problem to be solved before it consented to joining the WTO. ${ }^{166}$

The term "protocol" has a venerable history in the GATT. Protocols were used to implement the results of trade negotiations, to amend the GATT, and to effectuate accession through a Protocol of Accession. ${ }^{167}$ Unlike other treaties, ${ }^{168}$ the GATT did not authorize the use of the protocol instrument. Similarly, the WTO Agreement does not specifically authorize protocols. ${ }^{169}$ WTO Agreement Article IX (Decision-Making) does not do so nor does Article XII do so explicitly.

Nevertheless, given the long history of the use of protocols to implement GATT accession, there could very well a power to continue that GATT-era customary practice pursuant to WTO Agreement Article XVI:1. As I see it, the WTO uses a protocol to implement accession because that is how the GATT CONTRACTING PARTIES did so. But GATT accession protocols did not regularly contain GATT-plus obligations, so it would seem hard to argue that prior GATT practice itself justifies accepting any WTO accession protocol as an amendment to the WTO agreement that can establish wholly new enforceable obligations.

That the WTO Standard Protocol provides for registration at the United Nations might also connote an amendment, but such a conclusion would be unjustified. The very first free-standing

\footnotetext{
${ }^{166}$ An accession protocol for China might be able to fix the sequencing problem for cases involving China.

${ }^{167}$ Guide TO GATT LAW AND PRACTICE, supra note 33, at 1002-03, 1140-41.

${ }^{168}$ For example, Article 6.2(h) of the Vienna Convention for the Protection of the Ozone Layer provides authority to the Conference of the Parties to adopt protocols to the Convention.

${ }^{169}$ It is true that the foundation agreements establishing the WTO do contain the Marrakesh Protocol to GATT 1994, but this was not something adopted after the WTO went into force as the accession protocols are.
} 
accession protocol in the GATT, the Protocol with Japan of 1955, provided for registration at the United Nations, ${ }^{170}$ and yet that Protocol certainly did not contain any language that could have been viewed as amending the GATT. By contrast, contemporary WTO accession protocols do contain language (e.g., WTO-plus disciplines) that look amendment-like. But even that fact combined with U.N. registration does not demonstrate that these provisions truly are WTO amendments.

So far, the only formal amendment to an annex of WTO Agreement that has been adopted since the Marrakesh Ministerial is the addition of the new Article 31bis to the TRIPS Agreement and the new Annex. This amendment was adopted in 2005 by the WTO General Council by consensus and submitted to the members for acceptance pursuant to Article X of the WTO Agreement. The General Council Decision contains a "Protocol Amending the TRIPS Agreement” which states that it shall be registered under the provisions of the Charter of the United Nations. ${ }^{171}$ Although one can expect that a formal Article X amendment to the WTO would always provide for registration at the U.N. Secretariat, not everything that the WTO registers is necessarily a WTO amendment. One interesting practice that has developed regarding specific commitments for trade in services is that groups of "Members concerned" have adopted four "Protocols” to the GATS which were open for "acceptance” by individual members. ${ }^{172}$ These Protocols cover "Financial Services," the "Movement of Natural Persons," "Basic Telecommunications,” and "Financial Services” again. These Protocols purport to replace and/or supplement particular member schedules annexed to the GATS.

If the WTO-plus and minus terms are not an amendment to the WTO Agreement, then what are they? Certainly, as the above examples have shown, such terms do alter the baseline obligations in

\footnotetext{
${ }^{170}$ Protocol of Terms of Accession of Japan to the General Agreement on Tariffs and Trade, 7 June 1955, 220 UNTS 164, para. 9(c).

${ }^{171}$ Amendment of the TRIPS Agreement, WT/L/641 (8 December 2005), Protocol, para. 6.

${ }^{172}$ WTO Docs. S/L/11 (24 July 1995); S/L/12 (24 July 1995); S/L/20 (30 April 1996); S/L/45 (3 December 1997). These Protocols were directed to be registered with the U.N. Secretariat.
} 
WTO law. In my view, accession agreements are a legal instrument that modifies the WTO Agreement without being an actual amendment to it. ${ }^{173}$ The term "modified” appears in the GATT incorporation language which defines “GATT 1994” to be “GATT 1947” as "rectified, amended or modified by the terms of legal instruments which have entered into force before the date of entry into force of the WTO Agreement."174 “Modified” also appears in the Standard Protocol which states that

The WTO Agreement to which ...[name of applicant]... accedes shall be the WTO Agreement as rectified, amended or otherwise modified by such legal instruments as may have entered into force before the date of entry into force of this Protocol. ${ }^{175}$

An accession protocol is certainly a legal instrument that enters into force. It modifies the WTO prospectively by specifying the exact legal relationship between the acceded member and the incumbent members, and these obligations may well be different than exist in baseline WTO rules. An accession protocol may also establish reciprocal obligations between the applicant and the WTO.

Some analysts might object to my use of the word “modification.” Because no WTO law exists for a non-member, one might argue that the specialized obligations of the acceded member do not alter or modify the WTO Agreement because there was no pre-existing law for that member. That is true, but the analysis is unrealistic. As the percentage of members who join by accession grows, the WTO Legal Texts ${ }^{176}$ become increasingly out of date in specifying the legal relationships that exist because

\footnotetext{
${ }^{173}$ See FOOTER, supra note 13, at 241 ("The accession of a new Member is not usually thought of as an amendment but the WTO Agreement is modified ....”).

${ }^{174}$ GATT 1994, para. 1(a). This has particular reference to GATT Article XXVIII (Modification of Schedules) and to the Understanding on the Interpretation of GATT Article XXVIII.

${ }^{175}$ Standard Protocol, supra note 20, para. 2. Similar language appeared in Japan's Protocol of Accession and subsequent GATT accession protocols. Note that the Standard Protocol language is backward looking and does not say that the accession protocol is modifying the WTO.

${ }^{176}$ By this I mean The Legal TeXts. The Results of the Uruguay Round of Multilateral Trade NEGOTIATIONS (1999) which includes the Final Act Embodying the Results of the Uruguay Round of the Multilateral Trade Negotiations.
} 
with each new accession, binding specialized law is created. ${ }^{177}$ Consider the situation of Saudi Arabia which joined the WTO after China. To find China's obligations toward it, Saudi Arabia has to also look beyond the four corners of the WTO Legal Texts. Saudi Arabia must also look at China's accession protocol. Saudi Arabia will step into the same legal position toward China that incumbent members got when China joined (e.g., the WTO-minus). ${ }^{178}$ Thus for Saudi Arabia, the WTO Legal Texts were modified by China's earlier entry.

Another way to describe accession law, without using the term "modified," is that with each new accession, an additional set of country-specific law is layered on top of the WTO Agreement and the previous accession protocols. This new layer overwrites (or conditions ${ }^{179}$ ) the rules that would exist between two WTO members if they were incumbents. Eventually, the WTO Analytical Index will need to systematize the layers of new accession law and the related dispute settlement holdings regarding each particular accession protocol.

Based on the analysis above, the overall conclusion reached here is that if Accession Protocols are enforceable in the DSU, which I believe they are, they are enforceable for a reason that is extrinsic to whatever language is included in the Accession Protocol. The phrase "integral part of the WTO agreement” is not a set of magic words that transforms a Protocol that would otherwise be

\footnotetext{
${ }^{177}$ Note that the WTO website includes accession documentation on a page entitled "WTO legal texts."

${ }^{178}$ This conclusion seems reinforced by the fact that China, as a WTO member, is presumptively aware of the opportunities Saudi Arabia will gain, and that China could have vetoed Saudi Arabia's membership or invoked non-application against Saudi Arabia pursuant to Article XIII of the WTO Agreement. Thus, if China lets Saudi Arabia join, then China does so knowing that Saudi Arabia will gain the benefits of China's plus and minus commitments.

${ }^{179}$ According to the Appellate Body, "the legal character of the rights and obligations of the contracting parties under the GATT 1994 is not fully reflected by the text of the GATT 1994 because those rights and obligations are conditioned by the 'protocols', 'decisions' and other 'legal instruments' to which paragraph 1(b) [of the GATT 1994 incorporation language] refers.” Appellate Body Report, United States - Tax Treatment for “Foreign Sales Corporations”, WT/DS108/AB/R, adopted 20 March 2000, DSR 2000:III, 1619, para. 107.
} 
unenforceable into one that is enforceable. ${ }^{180}$ Instead, the justification for enforceability has to originate elsewhere than in the terms of an agreement that the WTO concludes with an applicant or with any other subject of international law.

\section{Explaining Enforceability}

The key to explaining the nature of accession protocols and their enforceability lies not in the protocols themselves, but rather in the language of WTO Agreement, and in particular Article XII:1 which provides: “Any State or separate customs territory possessing full autonomy in the conduct of its external commercial relations ... may accede to this Agreement, on terms to be agreed between it and the WTO.” The key term is "terms.” The language of Article XII makes clear that there is no such thing as a boiler-plate accession. The substantive terms of each accession are negotiated individually with the applicant. In stating that accession is to be accomplished through terms acceptable to both the WTO and the applicant, the WTO Agreement implies that the agreed "terms" will have continuing relevance long after the accession has occurred. The only way they can do so is if the terms of entry are enforceable. Were it not the case that the negotiated terms are enforceable, then what would be the point of negotiating them? It is true that if all of the terms of accession were fully carried out before the accession occurred, there might not be any need for enforceability. But so far, all WTO accession protocols have amounted to executory contracts and WTO-plus commitments are by their nature executory.

Thus, the solution to the puzzle of accession protocol enforceability is that both the structure and text of Article XII dictate that the accession commitments are enforceable through the DSU. Whether it would be possible for the WTO and the applicant to choose a different forum than the DSB

\footnotetext{
${ }^{180}$ Furthermore, for the reasons noted above, the phrase "integral part" cannot transform an otherwise uncovered agreement into "covered agreement." Perhaps the phrase "integral part" confirms enforceability, but that phrase cannot do the heavy lifting of making an accession protocol enforceable.
} 
presents an interesting question beyond the scope of this article. ${ }^{181}$ But in the absence of a different choice of forum, one can reasonably conclude that the WTO and the applicant comprehend that the terms of accession will be enforceable through the DSU.

Agreements "entered into pursuant" ${ }^{182}$ to Article XII are enforceable even though they are not one of the "covered agreements" listed in Appendix 1 of the DSU. This assertion may seem surprising, yet I believe it is fully consistent with the text of DSU Article 1.1 which states:

The rules and procedures of this Understanding shall apply to disputes brought pursuant to the consultation and dispute settlement provisions of the agreements listed in Appendix 1 to this Understanding (referred to in this Understanding as the "covered agreements"). The rules and procedures of this Understanding shall also apply to consultations and the settlement of disputes between Members concerning their rights and obligations under the provisions of the [WTO Agreement] ... and of this Understanding taken in isolation or in combination with any other covered agreement.

Therefore, when a WTO member has a dispute with another WTO member concerning rights and obligations under Article XII of the WTO Agreement, the complaining member could lodge a dispute solely under Article XII in isolation from any specific discipline in any other covered agreement. In other words, the cause of action for an accession compliance dispute should be Article XII along with the relevant discipline in the accession protocol. Viewing an accession compliance dispute as arising

\footnotetext{
${ }^{181}$ For example, using Permanent Court of Arbitration Optional Rules for Arbitration Involving International Organizations and States.

${ }^{182}$ I borrow this phraseology from the Model Special Exchange Agreement, referenced in supra note 65. The Model was still in use in 1994, when the GATT Secretariat drafted a Special Exchange Agreement with Taiwan which stated that the Agreement was "entered into pursuant to Article XV" of the GATT. GATT, Accession of Chinese Taipei, Spec(94)31 (22 August 1994), at 4-5.
} 
under ${ }^{183}$ Article XII deals with the practical problem of getting terms of reference for a panel which have to involve provisions of a covered agreement unless the parties to the dispute otherwise agree. ${ }^{184}$

In the first DSU panel request regarding accession disciplines, the three plaintiffs (Canada, the EC, and the United States), allege a number of violations of WTO agreements ${ }^{185}$ plus violations of China's particular accession commitments ${ }^{186}$ on auto parts. Canada goes further and also alleges a violation of the WTO Agreement, but does not list any particular provision as being violated.

\section{Non-Enforcement-The Nuclear Option}

I believe that panels will declare accession commitments enforceable, but the contrary position is worth considering briefly. How could a panel justify non-enforcement? If this is to be done, it would most likely happen with respect to applicant WTO-plus obligations. Non-enforcement of them could be supported by both textual and normative considerations.

The textual consideration would be that an accession protocol is not, strictly speaking, a covered agreement, but rather a legislative act of the WTO body that is not itself amenable to dispute

\footnotetext{
${ }^{183}$ According to the Appellate Body, “The DSU provides an integrated dispute settlement mechanism applicable to disputes arising under any of the "covered agreements.” Appellate Body Report, Brazil Desiccated Coconut, supra note 41, p. 13. Whether parties may by agreement extend the terms of reference beyond covered agreements is an issue that has not yet been litigated.

${ }^{184}$ See DSU art. 7.1.

${ }^{185}$ The WTO covered agreements invoked by one or more of the plaintiffs include the GATT, the TRIMS Agreement, and the SCM Agreement. China - Measures Affecting Imports of Automobile Parts, Request for the Establishment of a Panel by the United States, WT/DS340/8 (18 September 2006); Id. Request by Canada, WT/DS342/8 (18 September 2006); Id. Request by the EC, WT/DS339/8 (18 September 2006). The EC also states that China has acted inconsistently with the WTO Agreement “as set out” in China's Protocol, but the EC's request does not specify what provision(s) of the WTO Agreement is being violated. Nevertheless, the EC does not list the WTO Agreement as a cause of action.

${ }^{186}$ In particular, the China Protocol, supra note 21, Sections I.7.2 and I.7.3 and the Report of the China Working Party, supra note 92, paras. 93, 203. All of these are WTO-plus commitments. Canada also pointed to another commitment in the Protocol as a violation. In addition, the EC lodged a nonviolation complaint.
} 
settlement. The panel could acknowledge that demandeur governments insisted upon special accession terms that deviate considerably from the normal rules applying to incumbents, but then hold that the terms were only best-efforts political commitments, not legal ones. The panel could also suggest that even without the DSU, there will be some enforcement of accession terms through the market.

One normative consideration would be that accession protocols introduce unacceptable discrimination into the WTO system. After all, the Preamble to the WTO Agreement suggests that a major purpose of the WTO is "the elimination of discriminatory treatment in international trade relations.” Yet given the rampant discrimination that is explicitly permitted in the WTO Agreement, the argument that non-discrimination is constitutional principle of the WTO is facetious at best.

A better normative argument might be that WTO members enjoy de jure equality in the WTO regardless of how long they have been members of the WTO. ${ }^{187}$ In a recent address to the European Society of International Law, WTO Director-General Pascal Lamy extolled the "sovereign equality of States" as a principle of international law, and asserted that "This principle is fully respected in the WTO" and is "also reflected concretely in the substantial rules of the WTO.”188 Perhaps a panel might be inspired by this thought and hold that WTO law does not permit

\footnotetext{
${ }^{187}$ See Decision on the Acceptance of and Accession to the Agreement Establishing the World Trade Organization, reprinted in THE LEGAL TEXTS, supra note 176, at 409 ("Recognizing that the WTO Agreement does not distinguish in any way between WTO Members which accepted the Agreement in accordance with its Article XI and XIV and WTO Members which acceded to it in accordance with its Article XII .....”). WTO Agreement Article XIV is “Acceptance, Entry into Force and Deposit.”

${ }^{188}$ Pascal Lamy, "The Place and Role of the WTO (WTO Law) in the International Legal Order," Address before the European Society of International Law, 16 May 2006, available at $<$ http://www.wto.org/english/news_e/sppl_e/sppl26_e.htm>.
} 
second-class citizens. ${ }^{189}$ A panel might also be influenced by the critical views of some commentators about accession agreements. For example:

While it remains one of the enduring clichés of the multilateral trading system that the WTO is a "rule-based system," the actuality is that accession is inherently power based and hence the very antithesis of the WTO's credo. ${ }^{190}$ Roman Grynberg \& Roy Mickey Joy

Furthermore, acceding countries are required to make bigger commitments than the original members were. This creates a two-tiered system of rights and obligations for different members, thus substantially damaging the main principles of the WTO: non-discrimination, equal rights and transparency. ${ }^{191}$ Maxim Medvedkov

In the run-up to the 2006 G8 Summit in St. Petersburg, the Civil G8 (a group of over 300 civil society organizations from around the globe) issued a statement on "Trade, Finance for Development and Africa” which, among several points, urged the G8 to “declare that all countries, when negotiating their WTO membership, should not be charged with WTO-plus obligations or other non-favorable [ones] for national development conditions." ${ }^{192}$ Of course, the G8 governments had no use for that advice, and having acknowledged non-enforcement as a possibility, the paper will now return to fostering an understanding of the enforcement challenges.

\footnotetext{
${ }^{189}$ To his credit, Lamy tries to explain how sovereign equality can be reconciled with reverse discrimination in favor of developing countries, such as the generalized system of preferences. Lamy says that such mechanisms "ensure effective equality among Members" because "this adaptation of applicable rules to the real situation of States is a way of ensuring more genuine equality." This explanation, however convincing it may be regarding developing countries, would not be helpful in reconciling "sovereign equality" with the unequal accession commitments being demanded of many countries that join the WTO, including developing countries.

${ }^{190}$ Roman Grynberg \& Roy Mickey Joy, The Accession of Vanuatu to the WTO, 34(6) J. WORLD TRADE 159, 159 (2000).

${ }^{191}$ Maxim Medvedkov, WTO Accession: The Russian Perspective, in WTO ACCESSIONS AND DEVELOPMENT POLICIES, supra note 31, at 47, 48.

${ }^{192}$ Civil G8 - 2006 (9-10 March 2006), available at <http://en.civilg8.ru/>.
} 
Comparison of Accession Obligations

Chart 4 below shows the various types of existing accession obligations that are WTO minus or WTO plus, and distinguishes several key features:

\begin{tabular}{|c|c|c|c|c|}
\hline \multicolumn{5}{|c|}{ Chart 4. Types of Accession Obligations } \\
\hline & Done in GATT Era? & Discriminatory? & Protectionist? & Ultra Vires? \\
\hline Applicant WTO-minus & Yes & Yes & Yes & No \\
\hline Incumbent WTO-minus & Yes & Yes & Yes & No \\
\hline Applicant WTO-plus & Rarely $^{193}$ & Yes & No & No \\
\hline Incumbent WTO-plus & Rarely $^{194}$ & No & No & Possibly \\
\hline WTO WTO-plus & No & No & No & Possibly \\
\hline
\end{tabular}

One feature is whether this practice is new to the WTO. The two types of WTO-minus obligations were done in the GATT-era. Applicant GATT-minus was accomplished most notably through the grandfathering in Protocols of Provisional Application, ${ }^{195}$ and also through Accession terms. Incumbent GATT-minus was uncommon, but some existed. Some example of GATT-minus provisions were the GATT Accession Protocols of Hungary, Poland, and Romania which allow

\footnotetext{
${ }^{193}$ An Applicant GATT-plus was Poland's commitment to a quantitative increase in imports discussed in supra footnote 75.

${ }^{194}$ An Incumbent GATT-plus was the EC's' commitment discussed in the text accompanying supra note 67.

${ }^{195}$ The issue of whether the Protocol of Provisional Application would serve as a defense to a measure being challenged was litigated in several GATT cases with the matter often turning on whether the preaccession measure was mandatory. See, e.g., GATT Panel Report, Thailand - Restrictions on Importation of and Internal Taxes on Cigarettes, adopted 7 November 1990, GATT, BISD 37S/200, para. 83.
} 
incumbents to continue imposing discriminatory import restrictions against acceding countries. ${ }^{196}$ The Accession Protocol of Hungary also contains an incumbent GATT-minus safeguard, but with the twist of being reciprocal; in other words, the applicant Hungary was given the same GATT-minus opportunity. ${ }^{197}$

Another feature is whether the accession obligation is discriminatory. This occurs in Incumbent WTO-minus whereby an incumbent member can treat an acceded member less favorably than it treats other members; ${ }^{198}$ in Applicant WTO-plus whereby an acceded member has additional obligations that incumbent members do not; and in Applicant WTO-minus, where incumbent members have greater obligations than the acceded member. In Incumbent WTO-plus, all WTO members have a greater obligation than what is written in the WTO Agreement, but there is no discrimination (assuming that the acceded member has an equivalent obligation).

${ }^{196}$ Hungary Accession Protocol, supra note 66, para. 4; Poland Accession Protocol, supra note 75, para. 3; Protocol for the Accession of Romania to the General Agreement on Tariffs and Trade, GATT, BISD 18S5, para. 3. This treatment did not have a fixed termination date but was to be removed progressively. In a major address delivered in 1995, then WTO Director-General Renato Ruggiero recalled:

In the old days, centrally-planned economies such as Poland, Romania and Hungary were allowed to join the GATT in the absence of any serious economic reform effort. Special accession protocols were drawn up. These protocols recognized that trading opportunities would not be created by market forces, so they were based on import expansion commitments while allowing discriminatory trading arrangements to persist. But the political expediency and limited economic relevance of those arrangements have no place in the WTO today.

Renato Ruggiero, “The Global Challenge: Opportunities and Choices in the Multilateral Trading,” 16 October 1995 (emphasis added), available at <http://www.wto.org/english/news_e/sprr_e/harvar_e.htm>.

${ }^{197}$ Hungary Accession Protocol, supra note 66, para. 5. The Working Party Report explains that "Hungary could agree to the inclusion of a safeguard clause provided it operated on a reciprocal basis." Accession of Hungary, Report of the Working Party, GATT, BISD 20S/34, para. 9. The Romania Protocol contains a similar provision. Romania Accession Protocol, supra note 196, para. 4.

${ }^{198}$ Yang suggests that such provisions directed against China "could also seriously undermine the principle of non-discrimination.” Yongzheng Yang, Completing the WTO Accession Negotiations: Issues and Challenges, 22 THE WORLD ECONOMY 513, 528 (1999). 
In addition, Chart 4 displays two other features: One feature is whether the accession obligation is protectionist. That occurs in the two WTO-minus situations. The other feature is whether the WTO-minus or plus are ultra vires to the WTO’s competence. Given the lack of any legal standard in Article XII regarding the content of accession agreements, ${ }^{199}$ there may not be any accession terms that are ultra vires. ${ }^{200}$ Nevertheless, any employment of Incumbent WTO-plus or WTO WTO-plus is problematic because that can effectuate a change in the WTO Agreement that should be accomplishable only through an amendment.

The WTO-plus obligations for the WTO are especially odd, and their enforceability is questionable. For example, suppose the WTO fails to meet its commitment to Taiwan under the Special Exchange Agreement to "take measures, as are satisfactory to the [International Monetary] Fund, to ensure effective presentation of Chinese Taipei's case to the Fund, including, without limitation, the transmission to the Fund of any views communicated by Chinese Taipei to the WTO.”201 Could Taiwan lodge a case against the WTO in the DSB?

The instinctive answer of any trade lawyer might be no, but a more nuanced answer is called for. Recall that the DSU states that it will "apply to disputes brought pursuant to the consultation and

\footnotetext{
${ }^{199}$ Beyond the text of Article XII of the WTO Agreement, there is a WTO legal discipline for Special Exchange Agreements negotiated in connection with accession. GATT Article XV:7(b) states that the terms of a Special Exchange Agreement "shall not impose obligations on the contracting party in exchange matters generally more restrictive than those imposed" by IMF Articles on members of the Fund. JACKSON, supra note 77, at 486 (suggesting that this sets a maximum of restrictiveness). This discipline is not in conflict with Article XII and so is not trumped by Article XII.

${ }^{200}$ If some terms are ultra vires, it seems doubtful that an acceding member can challenge them after it joins the WTO because the member would be challenging the legitimacy of an agreement it reached with the WTO and that on which the applicant specifically agreed to be bound in joining the WTO. See Standard Protocol, supra note 20, para. 6 and the Vienna Convention on the Law of Treaties between States and International organizations or between International Organizations, 21 March 1986 (not in force), art 15. Perhaps estoppel could be invoked as a general principle of law. More gravely, is an illegal accession commitment separable from the Accession Protocol, or would an illegal accession provision invalidate the applicant's WTO membership? Before it joins the WTO, the applicant government would not have standing to invoke WTO dispute settlement.

${ }^{201}$ See text accompanying supra note 71.
} 
dispute settlement provisions” of the covered agreements, ${ }^{202}$ and no requirement exists in this head of jurisdiction for a member-to-member dispute. ${ }^{203}$ One of those covered agreements is the GATT and its Article XXIII provides for dispute settlement under several conditions including when any member should consider that any benefit accruing to it directly or indirectly under the GATT is being nullified or impaired as the result of "the existence of any other situation." "204 The two other conditions in GATT Article XXIII are a violation or a non-violation by another member; the third condition does not require that another member be the object of the complaint. Certainly, the GATT would be an appropriate covered agreement for Taiwan to use for jurisdiction because the Taiwan-WTO Special Exchange Agreement refers to GATT Article XV:6. Thus, in my view, Taiwan might be able to use the DSU to lodge a case against the WTO regarding the WTO’s failure. This would be a GATT Article XXIII:1(c) “situation” complaint.

Such a complaint would be unusual to be sure. ${ }^{205}$ The panel might not be able to issue a recommendation pursuant to DSU Article 19.1 because there would not be a "Member concerned" that is the object of the complaint. Nevertheless, the panel could investigate the matter and make

${ }^{202}$ See DSU art. 1.1

${ }^{203}$ See DSU arts. 6.1 (containing no requirement that the defendant be a Member); 7.1, 8.6, 12.1, 14.2, 16.3 (using the term “parties to" rather than “Members in”). But see DSU art. 3.3 (referring to benefits impaired by a member).

${ }^{204}$ GATT art. XXIII:1(c); DSU art. 23.1.

${ }^{205}$ To clarify, the unusual right of action discussed here applies only to Taiwan. For that plaintiff, my conclusion is reinforced by the language in the WTO's Special Exchange Agreement with Taiwan that provides "The Understanding on Rules and Procedures Governing the Settlement of Disputes of the WTO shall apply to disputes arising under this Agreement.” Special Exchange Agreement, supra note 64, art. VI:4. 
“findings” pursuant to the panel's authority in DSU Articles 7.1 and $11,{ }^{206}$ and perhaps could also make a "ruling” pursuant to the panel's authority in DSU Article 26.2. ${ }^{207}$ Whatever ruling the panel issues would have to be adopted by consensus in the DSB.

The political dynamics of accession would might if one WTO member were to lodge a complaint about the "excessive demands" ${ }^{208}$ of another in accession negotiations. ${ }^{209}$ Although WTO Article XII does not contain any legal standard that can be adjudicated, the General Council, as noted

${ }^{206}$ DSU Article 7.1 states in part:

Panels shall have the following terms of reference unless the parties to the dispute agree otherwise within 20 days from the establishment of the panel:

"To examine, in the light of the relevant provisions in (name of the covered agreement(s) cited by the parties to the dispute), the matter referred to the DSB by (name of party) in document ... and to make such findings as will assist the DSB in making the recommendations or in giving the rulings provided for in that/those agreement(s)."

\section{DSU Article 11 states in part:}

The function of panels is to assist the DSB in discharging its responsibilities under this Understanding and the covered agreements. Accordingly, a panel should make an objective assessment of the matter before it, including an objective assessment of the facts of the case and the applicability of and conformity with the relevant covered agreements, and make such other findings as will assist the DSB in making the recommendations or in giving the rulings provided for in the covered agreements.

${ }^{207}$ DSU Article 26.2 states in part:

Where the provisions of paragraph 1(c) of Article XXIII of GATT 1994 are applicable to a covered agreement, a panel may only make rulings and recommendations where a party considers that any benefit accruing to it directly or indirectly under the relevant covered agreement is being nullified or impaired or the attainment of any objective of that Agreement is being impeded as a result of the existence of any situation other than those to which the provisions of paragraphs 1(a) and 1(b) of Article XXIII of GATT 1994 are applicable. Where and to the extent that such party considers and a panel determines that the matter is covered by this paragraph, the procedures of this Understanding shall apply only up to and including the point in the proceedings where the panel report has been circulated to the Members.

\footnotetext{
${ }^{208}$ At the General Council meeting that approved the accession of Saudi Arabia, the Chairman of the Working Party (Munir Akram from Pakistan) took note of the challenge of "sometimes excessive demands made on acceding countries to accept obligations beyond those required by WTO agreements”). Minutes of Meeting held on 11 November 2005, WT/GS/M/99, para. 3.

${ }^{209}$ The WTO Director-General would not have standing to lodge such a complaint on behalf of the WTO even though the WTO ostensibly is an interested party in the accession process.
} 
above, did act in 2003 to approve a Decision on the Accession of Least-Developed Countries that includes, inter alia, the following "guidelines":

$\cdots$

WTO Members shall exercise restraint in seeking concessions and commitments on trade in goods and services from acceding LDCs, taking into account the levels of concessions and commitments undertaken by existing WTO LDCs’ Members. $\cdots$

... commitments to accede to any of the Plurilateral Trade Agreements or to participate in other optional sectoral market access initiatives shall not be a precondition for accession to the Multilateral Trade Agreements of the WTO. ${ }^{210}$

Are the guidelines enforceable? On first reading, these provisions may sound like they are. Yet the Decision does not say that it is enforceable in dispute settlement and instead states that the implementation of these guidelines shall be reviewed regularly in the agenda of the Subcommittee on Least Developed Countries (LDCs) of the Committee on Trade and Development, and that Ministers shall take stock of the situation. This might imply that the General Council committed the guidelines to the political process at the WTO rather than the legal process. $^{211}$

${ }^{210}$ Accession of Least Developed Countries, supra note 49, para. 1.

${ }^{211}$ Note that if an excessive demand is made and agreed to, incumbents that object can keep use consensus decisionmaking to keep that term from being inscribed in the accession protocol. 
On the other hand, when the General Council has wanted to clarify that a Decision it adopted would not be enforceable in dispute settlement, the Council has used specific language to say that. For example, in the August 2004 decision on the post-Cancún negotiating package, there was language in the decision stating: "The General Council agrees that this Decision and its Annexes shall not be used in any dispute settlement proceeding under the DSU and shall not be used for interpreting the existing WTO Agreements." ${ }^{212}$ Yet such language does not appear in the LDC Accession Guidelines.

Even though the General Council's Decision is not a covered agreement, is it possible that something in that decision could be enforceable? Perhaps yes so long as one member seeks to bring a case against another. Recall that the jurisdiction of the DSB extends to "consultations and the settlement of disputes between Members concerning their rights and obligations under the provisions of the Agreement Establishing the World Trade Organization" ... and of the DSU "taken in isolation or in combination with any other covered agreement.”213 No requirement explicitly exists that the legal provision to be enforced be part of the text of a covered agreement so long as it has become an obligation "under" the WTO Agreement. Jurisdiction could then be founded on Article XII of the WTO Agreement or Article IV:1 on decisionmaking. ${ }^{214}$ (Many WTO law experts would probably disagree with my conclusion.) Of course, the most obvious plaintiffs regarding unfair accession conditions are the countries that do not have standing to lodge complaints at the WTO — that is, the applicant countries that are not yet WTO members.

\footnotetext{
${ }^{212}$ Decision, WT/L/579 (2 August 2004), para. 2.

${ }^{213}$ DSU art. 1.1.

${ }^{214}$ Article IV:1 states, in part, that "The Ministerial Conference shall have the authority to take decisions on all matters under any of the Multilateral Trade Agreements, if so requested by a Member, in accordance with the specific requirements for decision-making in this Agreement and in the relevant Multilateral Trade Agreement.”
} 
Article XII is one of several provisions in the WTO Agreement that give authority to political bodies to take decisions. Amendments to the WTO under Article X will alter WTO law. For the other provisions, they cannot amend WTO law, but they can be capable of modifying WTO law. Chart 5 contains a list of such provisions in the WTO Agreement: 


\section{Chart 5}

Authorities in WTO Agreement for Decisionmaking by the WTO or WTO Bodies

\begin{tabular}{|c|l|}
\hline WTO Agreement & \multicolumn{1}{|c|}{ Nature of Authority } \\
\hline Art. III:5 & $\begin{array}{l}\text { Cooperation with the International Monetary Fund and the } \\
\text { World Bank }\end{array}$ \\
\hline Art. IV:1 & $\begin{array}{l}\text { Decisions on all matters under any of the Multilateral Trade } \\
\text { Agreements }\end{array}$ \\
\hline Art. V:1 & $\begin{array}{l}\text { Arrangements for cooperation with intergovernmental } \\
\text { organizations }\end{array}$ \\
\hline Art. V:2 & $\begin{array}{l}\text { Arrangements for cooperation with nongovernmental } \\
\text { organizations }\end{array}$ \\
\hline Art. VIII:5 & Headquarters agreement \\
\hline Art. IX:2 & Interpretations \\
\hline Art. IX:3 & Waivers \\
\hline Art. X & Amendments \\
\hline Art. XII:1 & Accession agreements \\
\hline
\end{tabular}


For each of these provisions, there is, in effect, a horizontal shelf extending outward from the WTO Agreement that contains the legislation approved. Whether such legislation modifies WTO law and whether such legislation is enforceable in the DSU are questions that call for careful analysis. With accession agreements, each of them add an additional and unique strata of law to the WTO Agreement.

\section{Some Challenges of Interpretation and SCOO}

Having justified enforceability of accession commitments in Part III, this study, in Part IV, now turns to challenges for panels and arbitrators in interpreting accession commitments and the WTO rules related to accession. In EC - Computer Equipment, the Appellate body explained that "The purpose of treaty interpretation is to establish the common intention of the parties to the treaty."215 Taken literally, this dictum suggests that for an accession agreement, the common intentions of the WTO and the applicant are to be ascertained and articulated. ${ }^{216}$

What does it mean to establish the intentions of the WTO? In one school of thought, the notion is that an international organization has a will and conscious personality its own; for this school, the WTO itself can have a chosen intention. ${ }^{217}$ By contrast, my own view is that one should not overpersonify international organizations and ascribe outcomes (and responsibilities) to them that are actually sourced in the interaction of governments.

\footnotetext{
${ }^{215}$ Appellate Body Report, European Communities - Customs Classification of Certain Computer Equipment, WT/DS62/AB/R, WT/DS67/AB/R, WT/DS68/AB/R, adopted 22 June 1998, DSR 1998:V, 1851, para. 93.

${ }^{216}$ This might mean that the Vienna Convention on the Law of Treaties is inapplicable since it deals only with treaties between states (see art. 1). If so, then the Vienna Convention on the Law of Treaties between States and International Organizations or between International Organizations would apply (once it comes into force) which has identical provisions on the interpretation of treaties between negotiating organizations and contracting states.

${ }^{217}$ See, e.g., Claire R. Kelly, Power, Linkage and Accommodation: The WTO as an International Actor and Its Influence on Other Actors and Regimes, 24 BERKELEY J. INT’L L. 79, 82 (2006) (“As an entity able to promote and, to some extent, enforce its own norms, the WTO has risen to the level of an international actor.”).
} 
An international organization is more of a forum for the interplay of actors than it is an actor in its own right. This is especially true of an international organization like the WTO that adheres to consensus decisionmaking and revels in being member-driven. Thus, in considering the meaning of an accession agreement, one should not hesitate to pierce the WTO veil in order to consider the intentions of incumbent WTO members rather than just the intention of the WTO itself.

\section{Legal Interpretation - Hierarchy}

A central problem of interpretation of accession agreements is where they fit in the hierarchy of WTO law. In the event of a conflict, the WTO Agreement is superior to the multilateral trade agreements on goods, services, and intellectual property. ${ }^{218}$ In Part III, I suggest that the drafters of the WTO Agreement should have written in an Article XII Annex for Accession Agreements. Had they done so, the hierarchical superiority of accession protocols vis-à-vis the multilateral trade agreements would have been crystal clear. Because the drafters did not do that, a WTO panel considering an accession protocol will be faced with having to decide where the protocol is positioned in WTO law. This task will necessarily entail a great deal of discretion by panels and make cross the interpretation and rulemaking. ${ }^{219}$

This question of hierarchy will not arise in every WTO case about accession obligations. Hierarchy seems most likely to arise in a complaint by an acceding government against an incumbent exercising its WTO-minus prerogatives. ${ }^{220}$ Hierarchy seems unlikely to be a central question in a

${ }^{218}$ WTO Agreement, art. XVI:3.

${ }^{219}$ See Holt, supra note 27, at 457, 469, 478 (arguing that panel will have to make common law and this task will undermine the legitimacy of WTO).

${ }^{220}$ One can imagine a panel suggesting that accession commitments are lex specialis to a multilateral agreement (e.g., the Agreement on Safeguards), rather than specifically addressing the question of hierarchy. But before a panel should denote an accession commitment as specialized law, the panel logically ought to first explain why the accession commitment is WTO law in the first place, and whatever that explanation is should point to a place in the WTO hierarchy of law. 
complaint arising out of an applicant WTO-plus provision because there would be no WTO law to conflict with. The question of hierarchy can also arise in situations where accession provisions are written to clarify existing WTO provisions.

The China Accession Protocol contains language that seems intended to assert that the Protocol term is hierarchically superior to the related multilateral agreements. Specifically, the China Protocol introduces some of its GATT-minus provisions by stating that GATT Article VI, the Antidumping Agreement, and the SCM Agreement "shall apply in proceedings involving imports of Chinese origin into a WTO Member consistent with the following” provisions. ${ }^{221}$ This language was probably intended to declare that the listed WTO agreements can only be applied insofar as they are consistent with the Protocol, but one cannot know for sure because the language is so ambiguous. Moreover, as noted above, the text of an Accession Protocol is no place to find an authoritative answer to its proper hierarchy in WTO law.

Perhaps the clearest looming problem is that several accession agreements make commitments with reference to specific WTO provisions without alluding to exceptions that might be available. ${ }^{222}$ For example, Albania committed that its laws and regulations relating to trade in goods would be in conformity with GATT Articles III:2 and III:4. ${ }^{223}$ If an accession protocol is superior to the GATT, then any accession obligation would trump the exceptions in GATT Article XX and XXI (in the event of a conflict). This reading might be reinforced by the reverse implication of a similar commitment in Cambodia's accession documentation that goes on to say that the commitment is "without prejudice to requirements that might be placed on distributors of domestic and imported products to preserve, plant,

${ }^{221}$ China Protocol, supra note 21, Section I.15.

${ }^{222}$ Qin, supra note 17 , at 518.

${ }^{223}$ Report of the Working Party on the Accession of Albania to the World Trade Organization, WT/ACC/AL/51 (13 July 2000), para. 46. Similar statements are included in the working party reports for Armenia, Croatia, Estonia, the Former Yugoslav Republic of Macedonia, Georgia, Jordan, the Kyrgyz Republic, Latvia, Lithuania, Moldova, Nepal, Oman, and Saudi Arabia. 
animal or human health, life or safety.”224 This provision might show that when the WTO and the applicant intended for the GATT's exceptions to remain relevant, the two accession parties specifically referenced them. A strict reading of Albania's commitment might also be suggested by the many commitments in accession protocols that do reference GATT Articles XX and XXI. For example, Panama agreed that the authority of its government to suspend imports and exports or to impose licensing requirements would be applied "in conformity with the requirements of the WTO, in particular Articles XI, XIII, XVIII, XIX, XX, and XXI of the GATT $1994 \ldots$. ..”225

Are there any other hierarchical choices available for a panel other than creating a legal fiction that accession agreements are located in an implied annex to the Article XII of the WTO Agreement? The most obvious option is the opposite position — that accession agreements are inferior to all other WTO law. This option would not seem attractive, however, because it would dignify the applicant WTO-plus provisions (that are not in conflict with specific provisions in pre-existing WTO law) while toppling the applicant WTO-minus and incumbent WTO-minus provisions that are in conflict with WTO law.

Legal Interpretation - Harmony

The question of harmony relates to the resolution of the question of hierarchy. If the accession protocol is thought to be higher law than a multilateral trade agreement, then the task of harmonizing

\footnotetext{
${ }^{224}$ Report of the Working Party on the Accession of Cambodia, WT/ACC/KHM/21 (15 August 2003), para. 50. The reference to "safety" may make this provision applicant WTO-minus because "safety" is not specifically included in GATT Article XX.

${ }^{225}$ Report of the Working Party on the Accession of Panama to the World Trade Organization, WT/ACC/PAN/19 (20 September 1996), para 42. Similar statements are included in the working party reports for Bulgaria, Croatia, Estonia, Jordan, the Kyrgyz Republic, Latvia, Lithuania, and Mongolia. It is interesting to note that Mongolia further stated that it would apply licensing only when necessary to protect human, animal and plant life and "the environment." Report of the Working Party on the Accession of Mongolia, WT/ACC/MNG/9 (27 June 1996), para. 20. The reference to the environment may make this provision applicant WTO-minus because the Agreement on Import Licensing Procedures does not seem to allow the GATT Article XX exception. See Agreement on Import Licensing Procedures, art. 1.10.
} 
them becomes easier. A panel would probably begin with the accession protocol (and its working party report) and use any analog provision in a multilateral trade agreement merely as a gap filler. On the other hand, if the accession protocol is not thought to be higher law, a panel could anchor its analysis in the covered agreement and use the accession protocol as a gap filler. However a panel proceeds, there will be a question of how much harmony to seek between an accession agreement and the multilateral trade agreements, and between two or more accession agreements. Striving for such harmony would enhance the overall coherence of WTO rules and the predictability of adjudicative outcomes. $^{226}$

A typical provision in accession agreements is for an accession term to refer to an analog rule in the annexes to the WTO Agreement. As noted above, this reference may be intended to alter the meaning of a normal WTO rule. Alternatively, the reference may be intended simply to illustrate the expected implementation of the normal rule. It will not always be clear to the treaty interpreter what the intentions of the WTO and the applicant were. For example, if an accession agreement makes no mention of an obvious analog provision, should that omission be construed as meaningful? Consider the China Protocol's terms for the product-specific safeguard which do not refer to the WTO Agreement on Safeguards. ${ }^{227}$ In that situation, uncertainty exists as to whether the extensive procedural disciplines in the Agreement should apply. ${ }^{228}$

For questions like this, a treaty interpreter would consider the object and purpose of the WTOplus and minus provisions. This would present a problem when no rationale is stated in the accession

\footnotetext{
${ }^{226}$ For a general discussion of harmonious interpretation of WTO agreements, see Wolfgang Weiss, Security and Predictability under WTO Law, 2 WORLD TRADE REV. 183, 205-06 (2003).

${ }^{227}$ Fabio Spadi has argued that "a substantial change from the 1997 version [of the draft Protocol] lies in the virtual disappearance of any direct reference to the Agreement on Safeguards as a sort of residual normative framework." Fabio Spadi, Discriminatory Safeguards in the Light of the Admission of the People's Republic of China to the World Trade Organization, 5 J. INT'L EcON. L. 421, 442 (2002).
}

${ }^{228}$ Lee, supra note 58, at 228-30. 
documentation. Yet Qin has pointed out that no rationale exists in the China Accession protocol and working party report for the differential treatment of China, ${ }^{229}$ and her observation seems valid with regard to all accession protocols.

For WTO-plus situations, the accession discipline may or may not have an analog in the WTO agreement. If there is no analog, then the panel presumably could consider the discipline to be selfcontained. This might be the case, for example, with Saudi Arabia’s industrial policy commitment regarding profits for liquid natural gas producers. ${ }^{230}$

With many accession agreements, a question will surely arise as to whether one accession agreement is valid “context” for another for purposes of treaty interpretation. The Appellate Body’s dictum quoted above ${ }^{231}$ would not be directly applicable because, at least formally, no accession agreement has the same two parties as another. But the Appellate Body went on to say that "the prior practice of only one of the parties may be relevant ...”232, so it might be possible to derive intention from prior accessions. Examining prior accession agreements could be useful, for example, it were thought that the difference between similar provisions in two accession protocols was unintended.

Another type of legal inconsistency that could arise are the provisions in accession agreements about export restrictions. For example, Lithuania agreed to impose export restrictions in conformity with GATT Article XI, ${ }^{233}$ while Oman agreed that its export control requirements "would be fully

\footnotetext{
${ }^{229}$ Qin, supra note 17, at 510. Qin may be a bit hasty in dismissing the China Working Party report.

${ }^{230}$ See text accompanying supra note 90.

${ }^{231}$ See text accompanying supra note 215.

${ }^{232}$ Appellate Body Report, EC - Computer Equipment, supra note 215, para. 93.

${ }^{233}$ Report of the Lithuania Working Party, supra note 124, para. 97.
} 
consistent with WTO provisions, including those contained in Article XI, XVII, XX and XXI of the GATT 1994.”234 Are these differences intentional or inadvertent?

One possible rule of interpretation is that given the importance of the GATT exceptions, the continued availability of them should be presumed unless the accession protocol language states otherwise. That would be attractive to me, but I wonder if it is consistent with the way in which the Appellate Body dealt with GATT Article XI in the US - Shrimp dispute in deciding whether the contested U.S. measure qualified for a GATT Article XX(g) exception. Recall that the Appellate Body pointed to a regional convention on sea turtles (in which the United States was a party) that reaffirmed GATT Article XI (without specifically mentioning the Article XX exception), and the Appellate Body saw that convention as relevant in showing "the continuing validity and significance of Article XI of the GATT 1994, and the obligations of the WTO Agreement generally, in maintaining the balance of rights and obligations ....”235 The inference one might draw from the US -Shrimp decision is that a specific commitment by a member to follow one GATT obligation will have weight in determining whether the member qualifies for a GATT exception to a violation of that obligation. I found the Appellate Body’s Shrimp decision surprising because I had always assumed that no reference to GATT Article XI in an environmental treaty was relevant in determining whether United States qualifies for the Article XX exception in the WTO.

Another problem is how to interpret exceptions in accession agreements that are reflected in an analog exception in a WTO covered Agreement. For example, in the Cambodia accession agreement discussed above, ${ }^{236}$ should the GATT Article XX chapeau be read into Cambodia's reference to measures for plant, animal or human health, life and safety?

\footnotetext{
${ }^{234}$ Report of the Working Party on the Accession of Oman to the World Trade Organization, WT/ACC/OMN/26 (28 September 2000), para. 77.

${ }^{235}$ Appellate Body Report, U.S. - Shrimp, supra note 23, paras. 169, 170.

${ }^{236}$ See text accompanying supra note 224.
} 
The same issue exists with Mexico’s GATT-era accession protocol, but with an additional wrinkle. Mexico’s Protocol states that Mexico will exercise its sovereignty over natural resources and that Mexico "may maintain certain export restrictions related to the conservation of natural resources, particularly in the energy sector, on the basis of its social and development needs if those export restrictions are made effective in conjunction with restrictions on domestic production or consumption.” ${ }^{237}$ This provision appears to be applicant GATT-minus on two counts: first, the explicit reference to "social" needs and second the lack of a reference to the requirements in the GATT Article XX chapeau. An interpretive question would be whether in a dispute against Mexico about an export restriction, Mexico could rely upon this provision as a broader defense than GATT Article XX.

For pre-WTO accession protocols like this and others, a prior question would be whether the old GATT-minus or GATT-plus provisions in the protocol of original WTO members were jettisoned upon accepting ${ }^{238}$ the WTO Agreement and joining the WTO. In my view, the GATT accession protocols have continuing vitality in the WTO. They are part of GATT $1994 .^{239}$

One interpretive issue regarding accession agreements that has been litigated is whether the acceding government accepts the WTO as it is. In the EC - Bananas III dispute, the EC offered the astonishing argument that as a new member entering the WTO through accession, Ecuador "fully accepted” the WTO, including the existing discriminatory quota allocations in the EC's schedule, and

\footnotetext{
${ }^{237}$ Protocol for the Accession of Mexico to the General Agreement on Tariffs and Trade, GATT, BISD 33S3, para. 5. Compare GATT art. XX(g).

${ }^{238}$ WTO Agreement, arts. XIV:1, XIV:2.

${ }^{239}$ See General Agreement on Tariffs and Trade 1994, para. 1(b)(ii) which defines GATT 1994 to include the GATT 1947 protocols of accession except for provisions concerning provisional application and grandfathering of prior inconsistent legislation. In the US - FSC case, the Appellate Body held that the GATT-era legal instruments "are, in themselves, 'integral parts' of the WTO Agreement and are "binding on all Members.” Appellate Body Report, US - FSC, supra note 179, para. 107. See also the Uruguay Round Decision on Notification Procedures which recalls "obligations assumed under the terms of specific protocols of accession, waivers, and other agreements entered into by Members,” reprinted in THE LEGAL TEXTS, supra note 176, at 388.
} 
was therefore estopped from challenging their legality. ${ }^{240}$ Quite rightly, the panel dismissed the notion that incumbents are automatically immunized, and held that a "new" member of the WTO would "have the same rights as those Complainants" who were parties when the quotas were allocated because "all Members benefit from all WTO rights."241

\section{Accession Commitments as Custom}

In view of the WTO norms in favor of member equality, another question that may arise in future dispute settlement is whether WTO-plus provisions can elevate to customary international trade law for which all WTO members are obliged to follow. ${ }^{242}$ I would guess that the U.S. governmentwhich is the most demanding of applicant WTO-plus provisions—-would be the first to deny that it could ever have an obligation to follow the same rules that acceded members have to follow. After all, WTO-plus accession disciplines are binding because they were consented to by applicants, and no such consent is given by incumbents.

Such a position is comprehensible, but one wonders how long it would stay tenable if a situation developed in which many acceded governments had committed to the same WTO-plus provision that was being actively enforced in dispute settlement. Even in the WTO, there may be a limit to how much of a double standard can be stomached. If a recurrent obligation in accession protocols were ever viewed by a panel as a generally applicable WTO obligation, the logic might be

\footnotetext{
${ }^{240}$ Panel Report, European Communities - Regime for the Importation, Sale and Distribution of Bananas, Complaint by Guatemala and Honduras, WT/DS27/R/GTM, WT/DS27/R/HND, adopted 25 September 1997, paras. IV.191-IV.194, as modified by the Appellate Body Report, WT/DS27/AB/R, DSR 1997:II, 695. The EC unsuccessfully made a similar argument in the Bananas I case. GATT Panel Report, EEC-Member States' Import Regimes for Bananas, DS/32/R (unadopted), paras. 128, 132, 361 (circulated 3 June 1993).

${ }^{241}$ EC - Bananas III (Guatemala and Honduras), supra note 1, paras. 7.92-7.93. Presumably, what the panel meant is that all members benefit from all WTO rights unless the acceding member specifically gives up a right during accession.
}

${ }^{242}$ At present, little if any WTO law is customary international law. It is all conventional law. 
that under the Vienna Convention on the Law of Treaties, the Protocol provision approved repeatedly by the WTO had become one of the "relevant rules of international law applicable in the relations between the parties.”243

Is there any possible solution to the contradiction between the most-favoured-nation principle and the imposition of applicant WTO-plus? In my view, the practice of making WTO-plus demands is unlikely to be reined in by WTO judicial or political bodies. Assuming that the WTO-plus norms are desirable for the trading system, perhaps the best solution would be to level all members up to that standard through new negotiations so that all members have to obey all prior WTO-plus provisions.

Yet that answer ignores the power relationships that engender WTO-plus provisions in the first place. One commentator has alleged that least-developed countries, like Vanuatu and Samoa, are facing demands in WTO negotiations that exceed commitments made by developed country incumbent members of the WTO. ${ }^{244}$ The explanation posited is that the least developed countries are "pawns in a global chess game” who are being used to establish "precedents” for more important future negotiations. $^{245}$

The possibility that the WTO-plus norms might someday lead to calls for upward harmonization of WTO law seems to have recognized by the negotiators in the China accession. For that reason, they included an "Introductory Statement” in the China Working Party Report stating that "Members reiterated that all commitments taken by China in her accession process were solely those of China and would prejudice neither existing rights and obligations of Members under the WTO

\footnotetext{
${ }^{243}$ See Vienna Convention on the Law of Treaties, art. 31.3(c), opened for signature 23 May 1969, 1155 UNTS 331.

${ }^{244}$ Jane Kelsey, World Trade and Small Nations in The South Pacific Region, 14 KAN. J.L. \& PuB. POL’y 247, 265 (2005).

${ }^{245} I d$.
} 
Agreement nor on-going and future WTO negotiations and any other process of accession.”246 The obvious retort is that China's commitments are hardly just unilateral. They are terms specifically agreed through consensus by the WTO. So the barrier to a multilateralization of WTO-plus accession commitments is political, nor normative. ${ }^{247}$

\section{SCOOing Accession Violators}

Suppose one WTO member complains about the violation of an accession protocol and a panel finds a violation, and then the acceded member fails to implement within the reasonable period of time allocated. In that situation, the next step would be for the complaining member to seek a SCOO. SCOO is an acronym for a suspension of concessions or other obligations, the remedy for nonimplementation provided in DSU Article 22. ${ }^{248}$ I prefer to use the term "SCOO" because it reflects the language in the DSU and because it does not have bellicose connotations of the alternative terms that commentators sometimes use like "retaliation" and "sanction.,"249

Would the complaining party be able to SCOO the acceded member? The answer is surely yes, but the usual procedures under DSU Article 22.3 might have to be adjusted because the Accession

\footnotetext{
${ }^{246}$ Report of the China Working Party, supra note 92, para. 9.

${ }^{247}$ Of course, some of the accession commitments written for transition economies will not have much meaning in market-oriented economies.

${ }^{248}$ DSU arts. 22.1, 22.6.

${ }^{249}$ See e.g., RoBert Z. LAWRENCE, CRIMES \& PUnishments. RETALIATION UNDER THE WTO (2003); WTO Secretariat, "Whose WTO is it anyway?", available at <http://www.wto.org/english/thewto_e/whatis_e/tif_e/org1_e.htm> (stating that “The rules are enforced by the members themselves under agreed procedures that they have negotiated, including the possibility of trade sanctions.”).
} 
Protocol is not an "agreement" as defined in DSU Article 22.3(g). ${ }^{250}$ Thus, the SCOO would not have to be limited to a “concession” or "other obligation” given by the complaining member in the Accession Protocol. Since any WTO dispute at its essence is about goods, services or intellectual property, a winning complainant should be able to fashion a SCOO even if no covered agreement has been violated other than Article XII of the WTO Agreement.

\section{Conclusion}

This article explores a new field—-the Law of WTO Accession. Unlike many other international organizations, the WTO does not have an open door to new members. Instead, joining the WTO through accession takes several years because each applicant government must first haggle its way in by reaching a deal with powerful WTO members, and must then secure official WTO approval of the multilateralized package. During the first decade of the WTO, its judicial bodies did not have to grapple with cases about a failure to conform to an obligation of accession. During the next ten years, such cases will occur.

The first and main target will be China which made many accession commitments about matters that went beyond the boundaries of the Uruguay Round single undertaking. China and other acceding members also made many accession commitments to conform to WTO law. Some of those

${ }^{250}$ DSU art. 22.3(g) states:

... for purposes of this paragraph, "agreement” means:

(i) with respect to goods, the agreements listed in Annex 1A of the WTO Agreement, taken as a whole as well as the Plurilateral Trade Agreements in so far as the relevant parties to the dispute are parties to these agreements;

(ii) with respect to services, the GATS;

(iii) with respect to intellectual property rights, the Agreement on TRIPS.

For a discussion of these procedures and principles, see DAVID PALMETER \& PETROs C. MAVROIDIS,

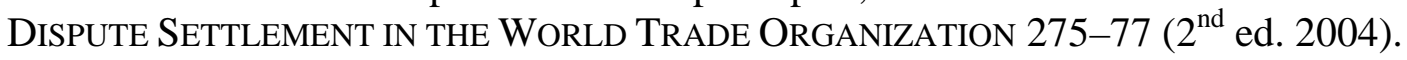


commitments will probably also engender WTO disputes, but in those instances, the claim of violation may be predicated only on the WTO Agreement and its annexes, not the applicable accession protocol.

The topic of WTO accessions is a fascinating one and scholarship has been impeded by the lack of a framework for distinguishing the various types of commitments being made and how they relate to general WTO law. The terms WTO-plus and WTO-minus are valuable descriptors, but they only make sense when attached to obligations not to so-called "WTO rights.” Many analysts have suggested that China's accession protocol entails a loss of WTO rights regarding safeguards, but the right lost is the right to expect other WTO members to adhere to the obligations in the WTO Agreement on Safeguards. In my view, a less roundabout and more exact way of describing this situation is not that China has lost its rights, but rather that incumbent WTO members have succeeded in reducing their obligations toward China lower than would have occurred if the rules for trade with China were set at the normal WTO legal baseline. In my view, the commonly used reference to a "right” of WTO members is meaningless in itself because there is no way to specify or delineate the content of such a right without direct reference to a WTO obligation.

Previous analysts of accession have attempted to characterize all accession commitments as plus and minus for the applicant and that approach does not work. The effect of WTO accession on incumbents needs to be explicitly considered and that consideration was largely absent from previous scholarship. My article has mapped out the new topic of WTO accession law by offering a typology of WTO-plus and minus commitments. Using the typology allows the analyst to think beyond the applicant and consider the changed circumstances of incumbents and the WTO itself. The invention of the new categories of incumbent WTO-plus and incumbent WTO-minus (see Charts 1, 2, and 3 above) should make it easier for future scholars on accession to clarify the legal developments and their implications. 
A WTO case about breaking an accession commitment will raise the issue of why accession agreements are enforceable through the DSU. So far, this matter has not been squarely addressed by any WTO panel or for that matter by any GATT panel. I do not doubt that panels will find an accession commitment to constitute a legitimate cause of action, but the way in which they rationalize the enforcement of such agreements will be important. No doubt an accession agreement is related to WTO law in the sense that it is an international agreement between the WTO and the applicant government. Nevertheless, before one jumps to the conclusion that any such agreement (with the WTO) is necessarily enforceable in the DSU, one should consider the implications of saying that the WTO Ministerial Council has authority to enter into an agreement with any other subject of international law (e.g., the United Nations) and then by joint consent use the DSB to resolve disputes. In my view, it will be important for the WTO judicature to justify enforceability in a way that does not have negative unintended consequences for the WTO. My article offers a blueprint for doing so.

A few thoughtful scholars have made an effort to solve the puzzle as to why accession protocols are enforceable in the DSB, but these explanations are not fully persuasive. WTO members surely intend accession agreements to be enforceable, and yet such a clear statement does not appear in accession agreements. Instead, the standard protocol states that it "shall be an integral part of the WTO Agreement.” For some analysts, that appears to solve the problem because if one agreement is an integral part of the WTO then it should be enforceable in the same way that any other part of the WTO would be. But that argument leads to the breathtaking implication that the WTO Ministerial Conference has the competence to approve other international agreements and then make them an integral part of the WTO or for that matter simply to write new WTO codes itself and avoid the cumbersome WTO amendment process in Article X of the WTO Agreement which involves “acceptance” by members. If the WTO Ministerial Conference does not have that competence, then how do we rationalize the legal valence of the phrase "integral part" when plunked into an accession accord yet not when plunked into other decisions of the Ministerial Conference. 
In my view, the phrase "integral part" is a distraction from the real reason why accession pacts are enforceable. The real reason is that Article XII of the WTO Agreement empowers the Ministerial Conference to conclude accession agreements in the name of the WTO, and such agreements are enforceable as Article XII agreements. The DSB's jurisdiction arises out of Article XII. In retrospect, the drafters of Article XII could have achieved greater clarity if they had written in that Article that accession agreements can be adjudicated in the DSU (or that accession agreements are "covered agreements") and then established an Annex to Article XII which would have been the "part" of the WTO that housed those individual agreements. Unfortunately, the drafters did not do so. In the absence of that clarity, the Ministerial Conference has seemingly tried to tidy up by stating within the accession agreement that it is an "integral part" of the WTO. It surely is, but the reason is the authority contained within Article XII itself, not the words of the Integral Clause contained only in the accession agreement.

The use of the term "Protocol" in "Protocol of Accession" is a borrowing from the GATT era and does not imply that it is the type of protocol that amends the WTO (such as the recent Protocol Amending the TRIPS Agreement). Because an accession protocol is not a WTO amendment, there is some tension between Article X of the WTO Agreement and the provisions in accession protocols that give obligations to all WTO members (what I call incumbent WTO-plus) or that give obligations to WTO bodies (what I call WTO WTO-plus). It may be ultra vires for the Ministerial Conference to adopt provisions of this sort by bypassing Article X (see Chart 4).

The most troubling legal development are the applicant WTO-plus provisions. By assigning to each new WTO member its own unique set of WTO obligations, the WTO undermines the rule of law in two ways—-first, by treating some members more favorably than others and second, by fragmenting the coherence of WTO law. Although I am not in principle opposed to broadening the scope of WTO law into new areas and to experimenting with new law (e.g., with plurilateral agreements), it does seem odd to me to conduct such experiments only on the newest members who are much more likely to have 
vulnerable economies than the governments (like the United States) who are designing the legal experiments.

The incumbent WTO-minus provisions do not provoke the same level of anguish in my opinion. These provisions delineate obligations of incumbent members toward the acceding member and water down the normal disciplines that would otherwise apply. That sort of incumbent WTOminus provision was an occasional GATT-era practice and such authorized protection is the sometimes the political price necessary to get incumbent governments to go along with opening up the multilateral trading system to new members. No doubt it is a double standard and belies the mantra that WTO members enjoy sovereign equality. ${ }^{251}$ Yet inequality seems to be the essence of the politically-driven, sometimes hegemonic, turbulent world trading system in the early $21^{\text {st }}$ century. That sad reality is, to be sure, glossed over by the WTO Secretariat when it declares on the WTO website that "in the WTO trading system, everyone has to follow the same rules.”252

Applicant WTO-plus has been the most fertile product of trade linkage in WTO negotiations over the past ten years. Detailed accession commitments have been made on many domestic policy issues that lie outside the current boundaries of the WTO. Commitments have also been made on trade policy that go well beyond current WTO rules. The success in incorporating these new norms into the WTO and making them enforceable in the DSU leads to the question as to whether these new norms should be multilateralized so that they become obligations of all WTO members, not just bilateral oneway obligations of the acceding member. Despite the official rhetoric in Geneva in favor of

\footnotetext{
${ }^{251}$ For an example of the mantra, see the March 2002 speech by WTO Director-General Mike Moore at the Qatar Conference on Democracy and Free Trade in which Moore declared: "The WTO system is built upon the rule of law and respect for the sovereign equality of nations.” Mike Moore, Democracy, Development and the WTO, 26 March 2002, available at <http://www.wto.org/english/news_e/spmm_e/spmm82_e.htm>.

${ }^{252}$ See supra note 83.
} 
multilateralism and member equality, I doubt that any effort in future negotiations will be made to level up all WTO-plus accession obligations so that they become binding on all members.

When panels get cases about accession agreements, many challenging conceptual issues of interpretation will arise. The central one is how to relate the accession commitment to regular WTO rules, particularly those that grant exceptions. It will be argued that accession commitments override such exceptions, and the outcome may depend on a solution to the puzzle of where an accession protocol fits into the hierarchy of WTO law. It is for that reason and others that I have urged in this article that the cause of action in any accession complaint be pleaded with the claim of a violation of WTO Agreement Article XII.

The possibility of WTO-plus and WTO-minus provisions only exists because applicant countries are so eager to join the WTO. ${ }^{253}$ That is because for all of its faults, the WTO is an effective and valuable international organization. Membership generates positive benefits to countries, both in legal security and in market confidence. Thus, applicant governments are willing to pay the price of WTO-plus and minus to join the WTO, ${ }^{254}$ and in some instances, elites in the applicant countries are probably eager to do so by transubstantiating a favored policy into an international obligation so that it will be harder to alter. In other words, applicants use Article XII to write a specialized unilateral

\footnotetext{
${ }^{253}$ See José E. Alvarez, INTERnATIONAL ORgANIZATIONS AS LAW-MAKERS 362 (2005) (suggesting that WTO membership gives a status in the community of states).

${ }^{254}$ The package of negotiated changes that an applicant government offers the WTO is in some sense an international public good as its benefits will be shared by all countries, or at least all WTO member countries. At present, no public debate exists within the WTO as to prioritizing the use of the WTO's leverage. Instead, the accession negotiations are decentralized with any interested WTO member demanding what it wants. This has led to a dynamic where the demands are driven by exporter special interests rather than an overall global community interest in promoting reforms in the applicant countries. See, e.g., Gary G. Yerkey, Veroneau Says Russia Must Do 'Much More' for U.S. To Favor WTO Accession Agreement, BNA DAILY RePORT FOR EXECUTIVES, 22 September 2006, at A-1) (noting U.S. demands on intellectual property and agriculture). One could argue that it would be far more important to press Russia to liberalize its political system and to cease crackdown on nongovernmental organizations. See Peter Finn, Russia Suspends Activities of NGOs in Clampdown on Dissent, IRISH Times, 21 October 2006, at 10.
} 
obligation of the acceding country, and then they opt into it via agreement with the WTO. This is a fascinating innovation on the international plane, and one that the DSB will be playing its part in the future to interpret, apply, and enforce. 